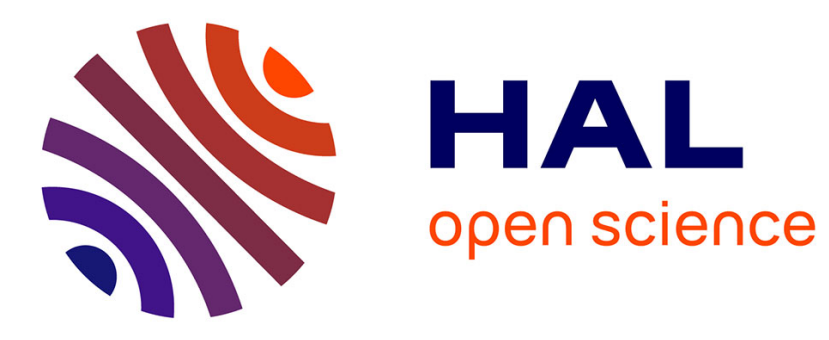

\title{
Workforce reconfiguration strategies in manufacturing systems: a state of the art
}

S. Ehsan Hashemi-Petroodi, Alexandre Dolgui, Sergey Kovalev, Mikhail Kovalyov, Simon Thevenin

\section{- To cite this version:}

S. Ehsan Hashemi-Petroodi, Alexandre Dolgui, Sergey Kovalev, Mikhail Kovalyov, Simon Thevenin. Workforce reconfiguration strategies in manufacturing systems: a state of the art. International Journal of Production Research, 2020, pp.1-24. 10.1080/00207543.2020.1823028 . hal-03052898

\section{HAL Id: hal-03052898 https://hal.science/hal-03052898}

Submitted on 10 Dec 2020

HAL is a multi-disciplinary open access archive for the deposit and dissemination of scientific research documents, whether they are published or not. The documents may come from teaching and research institutions in France or abroad, or from public or private research centers.
L'archive ouverte pluridisciplinaire HAL, est destinée au dépôt et à la diffusion de documents scientifiques de niveau recherche, publiés ou non, émanant des établissements d'enseignement et de recherche français ou étrangers, des laboratoires publics ou privés. 


\title{
Workforce reconfiguration strategies in manufacturing systems: a state of the $\operatorname{art}$
}

\author{
S. Ehsan Hashemi-Petroodi ${ }^{\text {a }}$ *, Alexandre Dolgui a , Sergey Kovalev ${ }^{\text {b, }}$ \\ Mikhail Y. Kovalyov ${ }^{c}$, Simon Thevenin ${ }^{\text {a }}$ \\ ${ }^{a}$ IMT Atlantique, LS2N-CNRS, La Chantrerie, 4, rue Alfred Kastler - B.P. 20722, 44307 Nantes Cedex 3, France \\ (e-mails: alexandre.dolgui@imt-atlantique.fr, seyyed-ehsan.hashemi-petroodi@imt-atlantique.fr, \\ simon.thevenin@imt-atlantique.fr) \\ ${ }^{b}$ INSEEC School of Business \& Economics \\ INSEEC U. Research Center, 25 rue de l'Université, 69007 Lyon, France \\ (e-mail: skovalev@inseec.com) \\ ${ }^{c}$ United Institute of Informatics Problems, National Academy of Sciences of Belarus, 220012 Minsk, Belarus \\ (e-mail: kovalyov_my@newman.bas-net.by)
}

\begin{abstract}
This paper provides a literature review and an analysis of the studies related to workforce reconfiguration strategies as a part of workforce planning for various production environments. The survey demonstrates that these strategies play a crucial role in the resilience and flexibility of manufacturing systems since they help industrial companies to quickly adapt to frequent changes in demand both in terms of volume and product mix. Five strategies are considered: the use of utility, temporary, walking, cross-trained workers, and bucket brigades. They are analyzed in the context of mixed and multi-model manual assembly lines, dedicated, cellular, flexible, and reconfigurable manufacturing systems. The review shows that most of the researches on these reconfiguration strategies focus on multi- or mixed-model assembly lines. At the same time, few studies consider workers team reconfiguration in flexible and reconfigurable manufacturing systems. Finally, this paper reveals several promising research directions in workforce reconfiguration planning, namely, the use of both machine and workforce reconfigurations, consideration of the ergonomic aspects, the combination of multiple workforce reconfiguration strategies, the study of workforce reconfiguration in human-robot collaborative systems, and the use of new technologies in human-machine industrial environments.
\end{abstract}

Keywords: Workforce planning, Workforce assignment, Flexibility, Reconfiguration strategies, Manufacturing systems.

*Corresponding author 


\section{Introduction}

Industrial companies are facing an increasing uncertainty in the future market demand, abrupt changes in customer needs, large product variety, and short product life cycles. Thereby, manufacturing companies switch from mass production to mass customization and individualization to be more adjustable and adaptable in terms of production capacity and functionality. This allows companies to quickly react to the changes in market and technology, and launch new products frequently. The achievement of this goal depends on reconfigurability, adaptability and flexibility of manufacturing systems. A new concept of reconfigurable manufacturing system was proposed by Koren et al. (1999), where resources can be rearranged, and replaced quickly to change the production capacity. Human workers, as a type of manufacturing resources, can easily be moved, added, or removed, which increase the reconfiguration capability of production systems. Therefore, human workers can play an important role in reconfiguration of manufacturing systems, and it is crucial for companies to investigate how human workers can be seen as a factor of reconfigurability.

There is a growing amount of literature on the reconfiguration of machines and equipment. In contrast, workforce reconfiguration is not enough analyzed. Nevertheless, humans are flexible by nature, and they represent an opportunity to enhance the flexibility of manufacturing systems. Unlike machines, which cannot perform a task beyond the scope of their predestination (at least to a certain degree), human workers are creative and able to operate with different tools and equipment. Moreover, a worker can handle a non-standard situation, where an automated resource would fail. Thus, the workers increase the flexibility and adaptability of manufacturing systems. 
This review explains which are possible strategies of workforce reconfiguration, how workforce reconfiguration and respective workforce planning help to make manufacturing systems more adaptive and resilient. The paper analyzes the five following workforce reconfiguration strategies: the use of utility, temporary or walking workers, bucket brigades, and cross-trained workers. Workforce planning problems are analyzed in various environments, such as dedicated manufacturing systems, mixed and multi-model manual assembly lines, cellular manufacturing systems, flexible manufacturing systems, and reconfigurable manufacturing systems.

Note that the present work is a follower of the conference paper (Dolgui, et al., 2019) where the literature on the workforce reconfiguration strategies is analyzed for mixed-model assembly lines. Here, the previous analysis is improved and extended to all types of manufacturing systems.

Studies on workforce planning in manufacturing systems were initiated by Akagi et al. (1983) and Shttjb (1984). Most of the following studies were done in the context of production scheduling problems. Several articles provided the states of the art on the existing advances in workforce planning research. The main topics of these review papers, sorted in the chronological order, are summarized in Table 1.

Table 1. Previous reviews on workforce reconfiguration strategies and workforce planning

\begin{tabular}{|l|l|}
\hline Paper & Main topic \\
\hline Baker (1976) & Workforce allocation in cyclical scheduling problems \\
\hline Stecke \& Aronson (1985) & $\begin{array}{l}\text { Classification of models and methods related to the worker/machine interference } \\
\text { problems }\end{array}$ \\
\hline Treleven (1989) & Characteristics of dual resource constrained (DRC) systems with flexibility of \\
& cross-trained workers \\
\hline Hottenstein \& Bowman (1998) & Simulation studies on DRC systems with flexibility of cross-trained workers \\
\hline
\end{tabular}




\begin{tabular}{|l|l|}
\hline Bratcu \& Dolgui (2005) & Modelling approaches for bucket brigades \\
\hline Bidanda et al. (2005) & Human-related problems in cellular manufacturing systems \\
\hline Xu et al. (2011) & Applications of DRC systems \\
\hline Quader (2013) & Applications and possible extensions of bucket brigades \\
\hline Van Den Bergh et al. (2013) & Personnel scheduling problems \\
\hline Ammar et al. (2013) & Workforce assignment issues in manufacturing systems \\
\hline Qin et al. (2015) & Workforce flexibility methods in operations management problems \\
\hline De Bruecker et al. (2015) & Workforce planning problems taking into account skills of the workers \\
\hline Bouajaja \& Dridi (2017) & Applications of workforce allocation problems \\
\hline
\end{tabular}

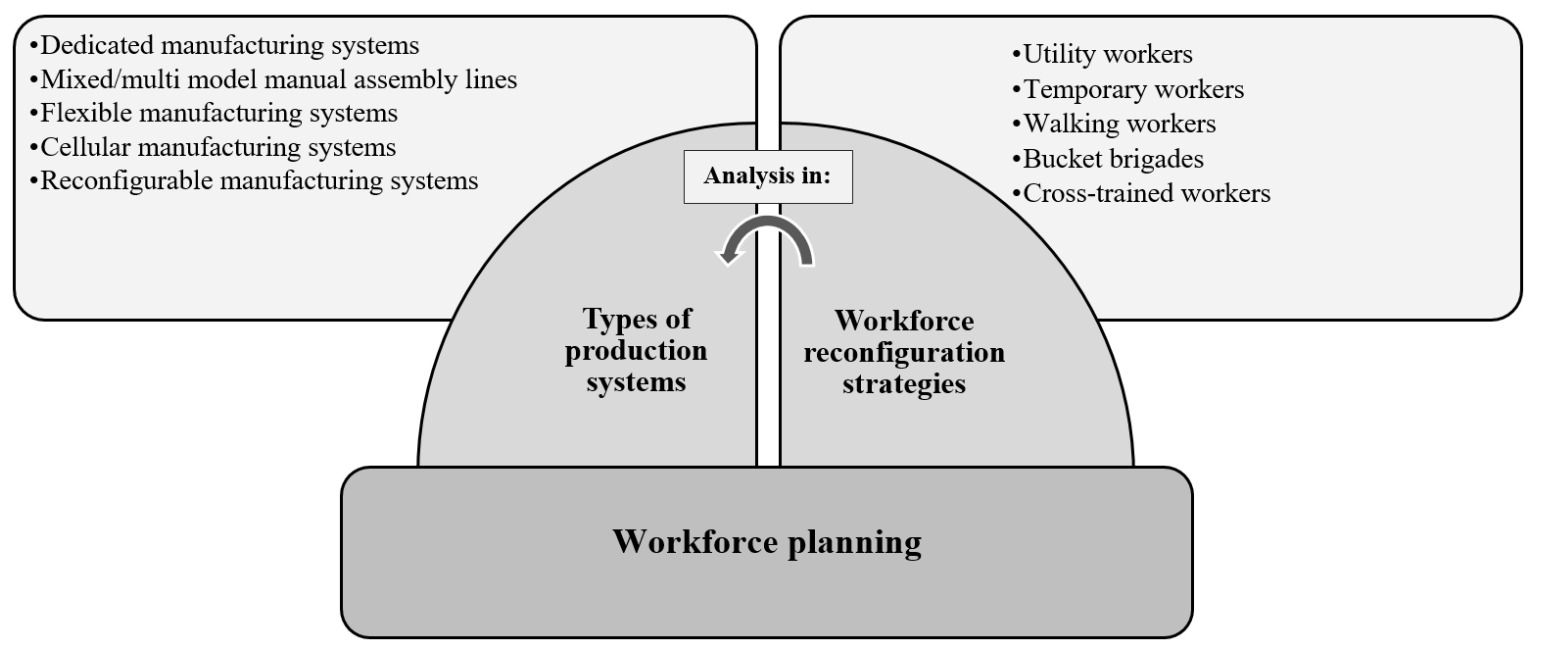

Figure 1. Framework of the paper.

This paper has two main objectives. First, unlike the previous reviews, this paper focuses on the impact of the workforce on the manufacturing system's reconfigurability, and second, revealing promising directions for future research in workforce planning in the context of reconfigurable manufacturing systems to increase their flexibility and efficiency. We mainly focus on the publications that appeared after 2005. 
(Qin et al., 2015) is the closest study to the present state of the art. There, the authors describe workforce flexibility instruments in terms of working time, and strategies such as overtime, flexible workdays, annualized hours, working time accounts, floaters (utility workers), crosstraining, teamwork and temporary workers irrespectively of the manufacturing configuration. In this paper, instead, we concentrate on the applications of these and other workforce reconfiguration strategies in various production environments.

The rest of this paper is organized as follows. Section 2 presents workforce planning in the manufacturing context and describes the main types of manufacturing systems. Section 3 reviews the literature related to the five workforce reconfigurability strategies that aim to enhance the adaptability and resilience of a manufacturing system. Section 4 provides the analysis of workforce reconfiguration strategies in different manufacturing systems and reveals promising research directions. Section 5 concludes the paper and future research directions.

\section{Workforce planning and manufacturing systems}

This section contains two subsections. The first presents workforce planning problems in the manufacturing context. The second describes the main existing types of manufacturing systems. The goal of this section is to have a better understanding of workforce planning, present its typical objectives and constraints, and describe different manufacturing systems workforce reconfiguration strategies.

\subsection{Workforce planning in manufacturing}

In the manufacturing context, workforce planning consists in determining the workforce capacity and assigning workers to the tasks. Workforce planning problems vary significantly depending on 
the nature of the items to produce, the type of the manufacturing system, the decisions to be made, and the optimization criteria.

Traditionally, a task is an indivisible amount of work to be performed on a product item. While mass production led to the design of production lines, which repetitively manufacture large series of the same item, mass customization drives towards multi-item manufacturing systems. When multiple items are produced, their sequences can be finite or infinite, repetitive or not, fully or partially specified.

In most studies, a single worker performs each task, and the task processing time is fixed. However, some studies consider that the processing time of a task depends on the quantity and characteristics of the assigned resources including workforce (Battaïa et al., 2015). These resource-dependent processing times can be deterministic, stochastic or uncertain due to, for example, the resources unavailability or production failures.

The shop floor's structure has a critical impact on workforce planning. In the classical flow shop setting, all tasks have the same routing from the first workstation to the last. However, in more complicated manufacturing systems, called job shops, tasks have different processing routes through the workstations. Some systems are constrained to process a single task per station, whereas others can perform several tasks sequentially or in parallel. In addition, industrial resources can induce various constraints on the task's allocation, such as space and time constraints. Finally, the timespan between two consecutive items moved from one station to the next one is a crucial characteristic of a manufacturing system. In a paced system, these moves follow the same time step, called cycle or takt time, for all stations. An essential characteristic of 
a paced production system is that the stations have no buffer to stock the incoming or outgoing products. In un-paced systems, buffers with a limited capacity are set between the stations.

Workforce planning is often combined with design, planning, and scheduling of a whole manufacturing system. In most cases, the physical layout and the composition of the processing and transporting equipment are decided before the workforce planning. However, several works have considered the case where the equipment is selected along with the workforce planning.

An optimization criterion is chosen depending on the need of the decision maker. The typical criteria related to the workforce are minimization of the labor costs, the number of workers in each production cycle, the ergonomic risks, the maximum workload, the workers' traveling distance, and maximization of the work variability and smoothness of the workload. Workforce planning aims to optimize efficiency criteria in different manufacturing systems: minimization of the cycle time, a function of the product completion times (usually in the case of the non-repetitive production), the equipment costs, the cost of the additional resources, maximization of the number of completed products per time unit. Sometimes, these criteria are replaced with the constraints limiting their values.

Note that, contrarily to the service industries, the workers in a manufacturing system follow regular shifts, and the workforce planning decisions usually do not account for the same work constraints and regulations.

\subsection{Types of manufacturing systems}

A manufacturing system can be characterized by the variability of manufactured products (Dolgui and Proth, 2010). In general, a system can be either dedicated to a single product type, in which 
case it is called a dedicated manufacturing system, or it can be designed to produce multiple product types. Besides, manufacturing systems vary with regard to their layout and the level of the flexibility. The literature on manufacturing systems that can handle various products can be categorized into publications on cellular, flexible, and reconfigurable manufacturing systems.

Dedicated manufacturing system (DMS). A DMS is a mass production system because it focusses on a high volume and low variety of products. Thereby, a DMS is characterized by relatively low costs and high throughput. Some examples are the transfer lines in automotive industry for machining cylinder blocks (Dolgui et al., 2009; Dolgui \& Ihnatsenka, 2009). The fixed structure of a DMS does not allow to increase the product variety or the throughput. The only way to enhance the flexibility of a DMS is to use several DMSs in parallel, where each DMS handles a specific product type (e.g., Özcan, 2018). A DMS can be reconfigured for new products, but it is costly and time consuming (Makssoud et al., 2014; 2020).

Flexible manufacturing system (FMS). An FMS can be efficient in situations where new products are introduced frequently, and companies are shifting from low-mix high-volume to lowvolume high-mix production, thus, require more flexibility. A high level of flexibility such that the new product requirements are adapted easily and quickly lead to the high initial investment for an FMS. An FMS is equipped with computer numerical control (CNC) machines connected by an automatic material handling system, where the numerical control is easily changed to process different tasks (Elmaraghy, 2005).

Reconfigurable manufacturing system (RMS). The concept of an RMS, introduced by (Koren, et al., 1999) is based on physical reconfiguration of equipment and other resources. Such system is able to adjust to different products of a product family. It is less costly than an FMS and offer a 
trade-off between the high throughput of a DMS and the universality of an FMS. An RMS is composed of the components such as workforce, machines, tools and material handling devices that can be easily added, removed or replaced. This system permits two levels of reconfiguration: (1) the system level, which changes connections between the components, (2) the components level, which changes the functionality of a component. Thanks to its ability to change the components, the RMS reduces setups and is able to change and adjust the production capacity and functionalities. (Bortolini, et al., 2018) give a comprehensive review on RMS research trends. They link reconfigurable manufacturing with Industry 4.0 technologies.

Note that FMS and RMS flexibilities are based on different concepts. An FMS is able to change its functionality without changing its physical configuration (except for tools), whereas an RMS is able to change its functionality by changing its physical configuration, modules and pieces of equipment. Both abilities are assumed to be cost effective.

Cellular manufacturing system (CMS). A CMS is an implementation of the Group Technology principles (Rajamani et al., 1990; Singh, 1993; Askin, 2013). A CMS comprises multiple cells, where each cell consists of a set of machines. Each cell is dedicated to the production of a given part family, where each family contains some parts with similar manufacturing requirements. Usually, the machine layout of the same cell is U-shaped to facilitate movements of the worker assigned to stations of the opposite sides of the cell.

While an FMS is highly flexible, but they have a limited capacity. A DMS is highly productive, but not flexible. Besides, a CMS can be considered as a compromise by using several dedicated cells instead of a sole DMS. However, their applicability is limited by the necessity of a rather predictable demand and a long lifecycle of the manufactured products (Benjaafar et al., 2002). An 
FMS does not have such constraints, but it is also costly, less productive and more complex. An RMS is less costly than an FMS, and it provides a customized flexibility when compared to the general flexibility existing in an FMS (Elmaraghy, 2005). In other words, an RMS creates the capacity and functionality that is needed, when it is needed. Thereby, in terms of capacity and functionality, an RMS may be placed between a DMS and an FMS (Mehrabi et al., 2000).

Assembly line. A lot of researches are dedicated to assembly line balancing and configuration problems, see the review papers of (Rekiek et al., 2002; Boysen et al., 2008; Battaïa \& Dolgui, 2013). Assembly lines represent a subclass of manufacturing systems, whose specificity consists in their flow shop nature and repetitive production. Assembly lines can be DMS, FMS, CMS or RMS. However, in terms of variety of products assembled on the line, assembly lines are commonly classified as dedicated, multi- or mixed-model lines (Bellgran \& Säfsten, 2009). Often manual assembly lines are studied. On multi-model manual assembly lines products of the same type are manufactured in batches, allowing a high level of productivity to the expense of low reactivity in product type changes. On mixed-model assembly lines (MMAL), products of different types can be produced in an arbitrary order, which increases the level of flexibility compared to the multi-model assembly lines. Dedicated assembly lines have the same properties as a DMS. They are designed to assemble a single product type with high throughput.

\section{Workforce reconfiguration strategies}

This section presents a classification of workforce reconfiguration strategies. The proposed classification of workforce reconfiguration strategies is based on the concept of reconfiguration of manufacturing systems (Koren et al., 1999; Mehrabi et al., 2000). A manufacturing system is called reconfigurable if it can modify its specific process capabilities, and subsequently adjust the 
production capacity to quickly respond to changes in the market demand. In a RMS, it is easy to add, remove, or interchange the components. In other words, the reconfiguration creates the capacity and functionality, which is needed, when it is needed.

The following subsections are dedicated to five workforce reconfiguration strategies studied in the literature. For every research paper related to a workforce reconfiguration strategy, we mention the studied problem's criterion, the type of the manufacturing system and the solution approach. The aim of this section is to know for which manufacturing systems workforce reconfiguration strategies were already studied in literature and for which this is still an open issue.

\subsection{Utility workers}

A task which cannot be executed completely within the workstation's takt time is called a utility work. It may create problems such as line stoppages, increased stocks of unfinished goods between stations, insufficient productivity and, as a result, unsatisfied demand. Utility workers assist permanent workers to complete such tasks. The problems are in designing algorithms to assign utility workers to the tasks. Most of them are scheduling problems. An assignment of utility workers to utility work can be considered as a reconfiguration of a manufacturing system as the allocation of workforce resources may vary from one cycle to another or from one product sequence to another. Table 2 presents the classification of the major studies related to the concept of utility workers, in which MMAL stands for mixed-model manual assembly lines.

Table 2. Articles related to utility workers

\begin{tabular}{|l|l|l|l|}
\hline Paper & Minimization of & $\begin{array}{l}\text { Type of the } \\
\text { system }\end{array}$ & Solution approach \\
\hline Hyun et al. (1998) & Utility work and setup cost & Straight MMAL & Genetic algorithm \\
\hline Celano et al. (2004) & Total stoppage time & U-shape MMAL & Genetic algorithm \\
\hline Yoo et al. (2005) & Weighted sum of line stops and idle time & Straight MMAL & $\begin{array}{l}\text { Simulated annealing and } \\
\text { Tabu search }\end{array}$ \\
\hline
\end{tabular}




\begin{tabular}{|l|l|l|l|}
\hline Boysen et al. (2011) & Number of overload situations & Straight MMAL & Exact and heuristics \\
\hline $\begin{array}{l}\text { Cevikcan \& } \\
\text { Durmusoglu (2011) }\end{array}$ & $\begin{array}{l}\text { Total utility work and utility worker } \\
\text { transfers }\end{array}$ & Straight MMAL & $\begin{array}{l}\text { Meta-heuristics and local } \\
\text { search }\end{array}$ \\
\hline Li \& Gao (2014) & Total regular and overtime labor costs & Straight MMAL & $\begin{array}{l}\text { Heuristic and branch-and- } \\
\text { bound-and-remember } \\
\text { algorithm }\end{array}$ \\
\hline $\begin{array}{l}\text { Cortez \& Costa } \\
\text { (2015) }\end{array}$ & Utility work needed & Straight MMAL & $\begin{array}{l}\text { Mixed integer programming } \\
\text { and heuristics }\end{array}$ \\
\hline Faccio et al. (2016) & Number of workers and work overload & Straight MMAL & Hierarchical approach \\
\hline Aroui et al. (2017) & Total work overload & Straight MMAL & $\begin{array}{l}\text { Mixed integer linear } \\
\text { programming, simulated } \\
\text { annealing, genetic algorithm }\end{array}$ \\
\hline
\end{tabular}

In these studies, a utility work mostly leads to line stoppages and increased workload. The studied problems are related to product sequencing (Yoo et al., 2005; Boysen et al., 2011; Cevikcan \& Durmusoglu, 2011; Cortez \& Costa, 2015), line balancing (Li \& Gao, 2014) and both sequencing and balancing (Faccio et al., 2016). One can notice that all these studies consider an MMAL. This is expected since assembly lines rely mainly on manual operations. Besides, product differentiation is often done in the assembly step, and assembly lines must be reconfigurable. The solution methods, which are mostly composed of heuristics and meta-heuristics, reflect, on one hand, the complexity of the studied problems and, on the hand, emphasize the importance of solution times.

These studies present various ideas of how utility workers may assist regular workers: sequentially, in parallel or replacing a regular worker completely. In (Celano et al., 2004), if a task is not completed on time, a utility worker intervenes and assists the regular worker in completing the task. Boysen et al. (2011) study the case where utility workers do not help, but rather replace regular workers to finish the task. Regular workers, in turn, start processing the next part. Utility workers that operate in parallel or after regular workers in the same cycle are called "jolly workers" (Faccio et al., 2016). A kind of utility workers is considered in (Aroui et al., 2017), where some workers work besides regular workers to minimize the overloading. Line balancing with a demand changing from shift to shift, both in terms of volume and product mix, is considered in (Li \& Gao, 
2014). (Cortez \& Costa, 2015) study a case, where heterogeneous regular workers are assisted by utility workers able to perform any task.

\subsection{Temporary workers}

Temporary workers can be used to help permanent workers. As the temporary workers are in most cases, less skillful than regular workers, they usually perform only a specific subset of tasks. Temporary workers improve the adaptability and, therefore, responsiveness of a manufacturing system in case of a high seasonal or uncertain demand (De Bruecker et al., 2015; Corominas et al., 2008; Francas et al., 2011). Table 3 summarizes the recent literature, which concentrates on the use of temporary workers and corresponding optimization problems.

Table 3. Studies concentrating on temporary workers

\begin{tabular}{|c|c|c|c|}
\hline Paper & Criteria & Type of the system & Solution approach \\
\hline $\begin{array}{l}\text { Stratman et al. } \\
(2004)\end{array}$ & Minimization of the total cost & Straight MMAL & $\begin{array}{l}\text { Discrete event } \\
\text { simulation }\end{array}$ \\
\hline $\begin{array}{l}\text { Techawiboonwong } \\
\text { et al. (2006) }\end{array}$ & $\begin{array}{l}\text { Minimization of workforce-related and } \\
\text { inventory costs }\end{array}$ & Straight MMAL & $\begin{array}{l}\text { Mixed integer } \\
\text { programming }\end{array}$ \\
\hline $\begin{array}{l}\text { Corominas et al. } \\
(2008)\end{array}$ & $\begin{array}{l}\text { Minimization of the number of temporary } \\
\text { workers }\end{array}$ & $\begin{array}{l}\text { Straight single- } \\
\text { model assembly } \\
\text { line }\end{array}$ & $\begin{array}{l}\text { Integer linear } \\
\text { programming }\end{array}$ \\
\hline Widyadana (2009) & $\begin{array}{l}\text { Minimization of the number of temporary } \\
\text { workers and the cycle time }\end{array}$ & $\begin{array}{l}\text { U-shape single- } \\
\text { model assembly } \\
\text { line }\end{array}$ & Goal programming \\
\hline Francas et al. (2011) & $\begin{array}{l}\text { Maximization of the difference of expected } \\
\text { second-stage profits and first-stage } \\
\text { investment costs }\end{array}$ & $\begin{array}{l}\text { Straight multi- } \\
\text { model assembly } \\
\text { line }\end{array}$ & $\begin{array}{l}\text { Two-stage stochastic } \\
\text { model }\end{array}$ \\
\hline $\begin{array}{l}\text { Manavizadeh et al. } \\
\text { (2013) }\end{array}$ & $\begin{array}{l}\text { Minimization of the total weighted idle } \\
\text { time, workload imbalance, uneven } \\
\text { distribution of idle time }\end{array}$ & U-shape MMAL & Simulated annealing \\
\hline $\begin{array}{l}\text { Buyukkaramikli et } \\
\text { al. (2013) }\end{array}$ & Minimization of the flexible crew cost & $\begin{array}{l}\text { Parallel single- } \\
\text { model assembly } \\
\text { line }\end{array}$ & $\begin{array}{l}\text { Transient behaviour } \\
\text { analysis of multi-server } \\
\text { queues }\end{array}$ \\
\hline Kim et al. (2018) & $\begin{array}{l}\text { Minimization of the total operating and } \\
\text { workers cost, the cycle time, and work } \\
\text { overload }\end{array}$ & Straight MMAL & $\begin{array}{l}\text { Integer and mixed } \\
\text { integer linear } \\
\text { programming and hybrid } \\
\text { genetic algorithm }\end{array}$ \\
\hline
\end{tabular}

Several researchers proposed solutions to workforce assignment problems where temporary and permanent workers have different skill levels (Stratman et al., 2004; Techawiboonwong et al., 
2006; Corominas et al., 2008; Manavizadeh et al., 2013; Kim et al., 2018). For example, in (Stratman et al., 2004) it was showed that allocating skilled permanent workers upstream of the production process leads to a better cost efficiency. In (Buyukkaramikli et al., 2013), the authors compared the hiring of temporary and permanent workers in a make-to-order production system. The cost incurred for a temporary crew is higher than the one for a permanent crew. However, it decreases as the length of the hiring period increases. The results showed that the highest cost reduction is achieved when the cost of a flexible crew equals the cost of a permanent crew.

In terms of the layout, Widyadana et al. (2009) studied a MMAL balancing problem with permanent and temporary workers, and they show that a U-shape line provides better results compared to a straight line.

\subsection{Walking workers}

Walking workers are not fixed to a given workplace and may follow the processed product until its last task. Upon completion, they return upstream to start processing a new product unit (AlZuheri et al., 2014). Several studies (Bischak, 1996; Deepak et al., 2017) showed that moving workers, whose dynamic reassignment allows increasing the workforce resource where and when needed, improve the performance of production lines and provide larger throughputs, larger resource utilization, and less work in process.

A walking worker can be skilled or unskilled, temporary or permanent. Chen et al. (2016) considered a so called "chasing-overtaking" production line, in which workers with high efficiency are allowed to overtake workers with low efficiency at workstations. The conducted simulation showed the superiority of the "chasing-overtaking" production line over traditional and bucket brigade (see Section 3.4) production lines in terms of production capacity and resource utilization. 
In (Pröpster et al., 2015), workforce-related reconfigurability is expressed in two ways: drifting of workers within a station and so-called "jumpers", i.e. workers able to intervene to any station if necessary. Table 4 presents the papers related to walking workers, classified by content/criteria, production system's type and solution approach.

Table 4. Studies related to walking workers

\begin{tabular}{|c|c|c|c|}
\hline Paper & Content or criteria & Type of the system & Solution approach \\
\hline Nakade \& Ohno (1995) & $\begin{array}{l}\text { The proof of the equality between the } \\
\text { sums of cycle times with original and } \\
\text { reverse order of task processing }\end{array}$ & $\begin{array}{l}\text { U-shape single-model } \\
\text { assembly line }\end{array}$ & Mathematical model \\
\hline Bischak (1996) & Maximization of the throughput & $\begin{array}{l}\text { U-shape single-model } \\
\text { assembly line }\end{array}$ & Simulation \\
\hline Zavadlav et al. (1996) & $\begin{array}{l}\text { Minimization of the number of } \\
\text { stations }\end{array}$ & U-shape MMAL & $\begin{array}{l}\text { Markovian and } \\
\text { simulation models }\end{array}$ \\
\hline $\begin{array}{l}\text { Sparling \& Miltenburg } \\
(1998)\end{array}$ & $\begin{array}{l}\text { Minimization of the number of } \\
\text { stations }\end{array}$ & U-shape MMAL & Heuristic \\
\hline Nakade \& Ohno (1999) & $\begin{array}{l}\text { Minimization of the overall cycle } \\
\text { time and the number of workforce }\end{array}$ & $\begin{array}{l}\text { U-shape single-model } \\
\text { assembly line }\end{array}$ & Heuristic \\
\hline Ahn et al. (2002) & Minimization of the total cost & $\begin{array}{l}\text { Parallel single-model } \\
\text { assembly line }\end{array}$ & Heuristic \\
\hline Zhao et al. (2004) & $\begin{array}{l}\text { Minimization of the total overload } \\
\text { time }\end{array}$ & Straight MMAL & Heuristics \\
\hline Süer \& Dagli (2005) & $\begin{array}{l}\text { Minimization of the total intra-cell } \\
\text { manpower transfers } \\
\text { Maximization of throughput }\end{array}$ & $\begin{array}{l}\text { Cellular manufacturing } \\
\text { system }\end{array}$ & $\begin{array}{l}\text { Mathematical } \\
\text { programming and } \\
\text { traveling salesman } \\
\text { approach, } \\
\text { McNaughton's } \\
\text { algorithm }\end{array}$ \\
\hline Ertay \& Ruan (2005) & $\begin{array}{l}\text { Maximization of the output to input } \\
\text { ratio }\end{array}$ & $\begin{array}{l}\text { Cellular manufacturing } \\
\text { system }\end{array}$ & $\begin{array}{l}\text { Data envelopment } \\
\text { analysis }\end{array}$ \\
\hline Bock et al. (2006) & $\begin{array}{l}\text { Minimization of the total cost related } \\
\text { to workforce and off-line repair }\end{array}$ & Straight MMAL & $\begin{array}{l}\text { Heuristics, simulated } \\
\text { annealing, and local } \\
\text { search }\end{array}$ \\
\hline Chaves et al. (2007) & $\begin{array}{l}\text { Maximization of the line's } \\
\text { productivity }\end{array}$ & $\begin{array}{l}\text { Straight single-model } \\
\text { assembly line }\end{array}$ & $\begin{array}{l}\text { Heuristic (Clustering } \\
\text { search) }\end{array}$ \\
\hline Wang et al. (2007) & $\begin{array}{l}\text { Minimization of the number of } \\
\text { workstations and the number of } \\
\text { walking workers }\end{array}$ & Straight MMAL & Simulation \\
\hline Battini et al. (2007) & Minimization of load and setup times & Straight MMAL & Heuristics \\
\hline Miralles et al. (2008) & Minimization of the cycle time & $\begin{array}{l}\text { Straight single-model } \\
\text { assembly line }\end{array}$ & Branch-and-bound \\
\hline $\begin{array}{l}\text { Nakade \& Nishiwaki } \\
(2008)\end{array}$ & $\begin{array}{l}\text { Minimization of the overall cycle } \\
\text { time and the number of workers }\end{array}$ & $\begin{array}{l}\text { U-shape single-model } \\
\text { assembly line }\end{array}$ & Heuristic \\
\hline Shewchuk (2008) & $\begin{array}{l}\text { Minimization of the number of } \\
\text { workers and maximization of the } \\
\text { workforce utilization }\end{array}$ & $\begin{array}{l}\text { U-shape single-model } \\
\text { assembly line }\end{array}$ & Heuristic \\
\hline Moreira \& Costa (2009) & Minimization of the cycle time & $\begin{array}{l}\text { Straight single-model } \\
\text { assembly line }\end{array}$ & Tabu search \\
\hline
\end{tabular}




\begin{tabular}{|c|c|c|c|}
\hline Simaria et al. (2009) & $\begin{array}{l}\text { Minimization of the idle time and } \\
\text { workload unbalance at stations }\end{array}$ & U-shape MMAL & $\begin{array}{l}\text { Ant colony } \\
\text { optimization and } \\
\text { heuristics }\end{array}$ \\
\hline $\begin{array}{l}\text { Yaakob \& Watada } \\
\text { (2009) }\end{array}$ & $\begin{array}{l}\text { Maximization of the system's } \\
\text { efficiency }\end{array}$ & $\begin{array}{l}\text { Cellular manufacturing } \\
\text { system }\end{array}$ & $\begin{array}{l}\text { Particle swarm } \\
\text { optimization }\end{array}$ \\
\hline Mahdavi et al. (2010) & $\begin{array}{l}\text { Minimization of total cost (holding, } \\
\text { backorder, machine, workers, } \\
\text { material handling) }\end{array}$ & $\begin{array}{l}\text { Dynamic Cellular } \\
\text { manufacturing system }\end{array}$ & Branch-and-bound \\
\hline $\begin{array}{l}\text { Sirovetnukul \& Chutima } \\
\text { (2010) }\end{array}$ & $\begin{array}{l}\text { Minimization of the number of } \\
\text { workers }\end{array}$ & U-shape MMAL & Heuristics \\
\hline Al-Zuheri et al. (2010) & $\begin{array}{l}\text { Minimization of the number of } \\
\text { workers and equipment costs }\end{array}$ & U-shape MMAL & $\begin{array}{l}\text { Simulation and } \\
\text { combinatorial } \\
\text { optimization }\end{array}$ \\
\hline Altemeier et al. (2010) & Minimization of the total cost & Straight MMAL & $\begin{array}{l}\text { Decision support tool } \\
\text { and heuristics }\end{array}$ \\
\hline Francas et al. (2011) & $\begin{array}{l}\text { Maximization of the difference of } \\
\text { expected second-stage profits and } \\
\text { first-stage investment costs }\end{array}$ & $\begin{array}{l}\text { Straight multi-model } \\
\text { assembly line }\end{array}$ & $\begin{array}{l}\text { Two-stage stochastic } \\
\text { model }\end{array}$ \\
\hline Soolaki (2012) & $\begin{array}{l}\text { Minimization of the cost and cells } \\
\text { load variation }\end{array}$ & $\begin{array}{l}\text { Dynamic Cellular } \\
\text { manufacturing system }\end{array}$ & $\begin{array}{l}\text { Multi-objective } \\
\text { genetic algorithm }\end{array}$ \\
\hline $\begin{array}{l}\text { Nikoofarid \& Aalaei } \\
(2012)\end{array}$ & $\begin{array}{l}\text { Minimization of holding and } \\
\text { backorder costs }\end{array}$ & $\begin{array}{l}\text { Dynamic Cellular } \\
\text { manufacturing system }\end{array}$ & Branch-and-bound \\
\hline Yang et al. (2013) & $\begin{array}{l}\text { Minimization of the number of } \\
\text { workstations, rebalancing cost and } \\
\text { workload unbalance }\end{array}$ & Straight MMAL & $\begin{array}{l}\text { Multi-objective } \\
\text { genetic algorithm }\end{array}$ \\
\hline Al-Zuheri et al. (2013) & $\begin{array}{l}\text { Maximization of line's productivity } \\
\text { and ergonomic performances }\end{array}$ & U-shape MMAL & $\begin{array}{l}\text { Mathematical model } \\
\text { and simulation }\end{array}$ \\
\hline Wang et al. (2013) & $\begin{array}{l}\text { Maximization of the performance: } \\
\text { flexibility, efficiency, responsiveness } \\
\text { and re-configurability }\end{array}$ & Straight MMAL & Simulation \\
\hline Eğilmez et al. (2014) & $\begin{array}{l}\text { Maximization of the production rate } \\
\& \text { minimization of the number of } \\
\text { workers }\end{array}$ & $\begin{array}{l}\text { Cellular manufacturing } \\
\text { system }\end{array}$ & $\begin{array}{l}\text { Hierarchical } \\
\text { approach }\end{array}$ \\
\hline Al-Zuheri et al. (2014) & $\begin{array}{l}\text { Evaluation of errors in the model } \\
\text { predictions of performance measures: } \\
\text { production rate, walking and waiting } \\
\text { times }\end{array}$ & U-shape MMAL & $\begin{array}{l}\text { Mathematical model } \\
\text { and simulation }\end{array}$ \\
\hline $\begin{array}{l}\text { Kucukkoc \& Zhang } \\
\text { (2014) }\end{array}$ & $\begin{array}{l}\text { Minimization of the number of } \\
\text { workstations }\end{array}$ & $\begin{array}{l}\text { Parallel two-sided } \\
\text { MMAL }\end{array}$ & $\begin{array}{l}\text { Agent-based ant } \\
\text { colony }\end{array}$ \\
\hline Savino et al. (2014) & $\begin{array}{l}\text { Maximization of workers' productive } \\
\text { capacities and minimization of } \\
\text { buffers levels }\end{array}$ & U-shape MMAL & Simulation \\
\hline Pröpster et al. (2015) & $\begin{array}{l}\text { Creation of tool for monitoring, } \\
\text { validating line balancing results and } \\
\text { forecasting }\end{array}$ & Straight MMAL & Simulation \\
\hline Battaïa et al. (2015) & $\begin{array}{l}\text { Minimization of the total number of } \\
\text { workers }\end{array}$ & Straight MMAL & $\begin{array}{l}\text { Linear programming } \\
\text { and randomized } \\
\text { heuristics }\end{array}$ \\
\hline Chen et al. (2016) & $\begin{array}{l}\text { Maximization of the production } \\
\text { capacity }\end{array}$ & $\begin{array}{l}\text { U-shape single-model } \\
\text { assembly line }\end{array}$ & Simulation \\
\hline Cevikcan (2016) & $\begin{array}{l}\text { Minimization of the number of } \\
\text { workforce and maximization of the } \\
\text { workload smoothness }\end{array}$ & $\begin{array}{l}\text { Straight Multi-model } \\
\text { assembly line }\end{array}$ & Heuristics \\
\hline
\end{tabular}




\begin{tabular}{|c|c|c|c|}
\hline Tapkan et al. (2016) & $\begin{array}{l}\text { Minimization of the number of } \\
\text { stations and workers' walking time }\end{array}$ & $\begin{array}{l}\text { Parallel single-model } \\
\text { assembly line }\end{array}$ & $\begin{array}{l}\text { Bee colony and } \\
\text { artificial bee colony }\end{array}$ \\
\hline $\begin{array}{l}\text { Kucukkoc \& Zhang } \\
\text { (2016) }\end{array}$ & $\begin{array}{l}\text { Minimization of the weighted } \\
\text { summation of line length and the } \\
\text { number of workstations }\end{array}$ & $\begin{array}{l}\text { Parallel two-sided } \\
\text { MMAL }\end{array}$ & $\begin{array}{l}\text { Agent-based ant } \\
\text { colony }\end{array}$ \\
\hline Jaehn \& Sedding (2016) & Minimization of the makespan & $\begin{array}{l}\text { Straight multi-model } \\
\text { assembly line }\end{array}$ & Heuristics \\
\hline Al-Zuheri et al. (2016) & Minimization of the total cost & U-shape MMAL & Genetic algorithm \\
\hline $\begin{array}{l}\text { Vairaktarakis et al. } \\
\text { (2016) }\end{array}$ & $\begin{array}{l}\text { Levelling criteria: maximization of } \\
\text { the workforce size and minimization } \\
\text { of the maximum workforce } \\
\text { fluctuation }\end{array}$ & Straight MMAL & Heuristics \\
\hline $\begin{array}{l}\text { Aljuneidi \& Bulgak } \\
\text { (2016) }\end{array}$ & Minimization of the total cost & $\begin{array}{l}\text { Dynamic Cellular } \\
\text { manufacturing system }\end{array}$ & $\begin{array}{l}\text { Integer nonlinear } \\
\text { programming model }\end{array}$ \\
\hline Liu et al. (2016) & $\begin{array}{l}\text { Minimization of backorder and } \\
\text { holding costs }\end{array}$ & $\begin{array}{l}\text { Dynamic Cellular } \\
\text { manufacturing system }\end{array}$ & Meta-heuristics \\
\hline Kellegöz (2017) & $\begin{array}{l}\text { Minimization of the number of } \\
\text { workers and stations opened in the } \\
\text { line }\end{array}$ & $\begin{array}{l}\text { Straight single-model } \\
\text { assembly line }\end{array}$ & Simulated annealing \\
\hline Deepak et al. (2017) & $\begin{array}{l}\text { Maximization of the resource } \\
\text { utilization and minimization of the } \\
\text { work in process }\end{array}$ & $\begin{array}{l}\text { Straight single-model } \\
\text { assembly line }\end{array}$ & Simulation \\
\hline Stadnicka et al. (2017) & $\begin{array}{l}\text { Minimization of the walking path of } \\
\text { the workers }\end{array}$ & $\begin{array}{l}\text { Straight single-model } \\
\text { assembly line }\end{array}$ & Simulation \\
\hline Sikora et al. (2017) & Minimization of the cycle time & Straight MMAL & $\begin{array}{l}\text { Mixed integer linear } \\
\text { programming }\end{array}$ \\
\hline Kuo \& Liu (2017) & $\begin{array}{l}\text { Minimization of the number of } \\
\text { workers }\end{array}$ & $\begin{array}{l}\text { Cellular manufacturing } \\
\text { system }\end{array}$ & $\begin{array}{l}\text { Mixed integer linear } \\
\text { programming }\end{array}$ \\
\hline Feng et al. (2017) & Minimization of the total cost & $\begin{array}{l}\text { Cellular manufacturing } \\
\text { system }\end{array}$ & $\begin{array}{l}\text { Particle swarm } \\
\text { optimization }\end{array}$ \\
\hline Lian et al. (2018) & $\begin{array}{l}\text { Minimization of the deviations from } \\
\text { the average workload of cells and } \\
\text { workers' number }\end{array}$ & $\begin{array}{l}\text { Cellular manufacturing } \\
\text { system }\end{array}$ & $\begin{array}{l}\text { Non-dominated } \\
\text { sorting genetic } \\
\text { algorithm }\end{array}$ \\
\hline Baykasoğlu et al. (2018) & $\begin{array}{l}\text { Minimization of machine and worker } \\
\text { duplication costs }\end{array}$ & $\begin{array}{l}\text { Cellular manufacturing } \\
\text { system }\end{array}$ & $\begin{array}{l}\text { Integer and constraint } \\
\text { programing }\end{array}$ \\
\hline Biele \& Mönch (2018) & $\begin{array}{l}\text { Minimization of labor and inventory } \\
\text { costs }\end{array}$ & Straight MMAL & $\begin{array}{l}\text { Random-key genetic } \\
\text { algorithm }\end{array}$ \\
\hline Dolgui et al. (2018) & $\begin{array}{l}\text { Minimization of the maximum } \\
\text { number of workers }\end{array}$ & Straight MMAL & $\begin{array}{l}\text { Mixed-integer linear } \\
\text { programming and } \\
\text { heuristics }\end{array}$ \\
\hline Gebennini et al. (2018) & $\begin{array}{l}\text { Minimization of the workers' } \\
\text { walking cost and ergonomic risks of } \\
\text { scheduled jobs }\end{array}$ & $\begin{array}{l}\text { Straight single-model } \\
\text { assembly line }\end{array}$ & $\begin{array}{l}\text { Mixed integer linear } \\
\text { programming }\end{array}$ \\
\hline Naderi et al. (2019) & $\begin{array}{l}\text { Minimization of the number of } \\
\text { workers }\end{array}$ & Five-sided MMAL & $\begin{array}{l}\text { Benders' } \\
\text { decomposition }\end{array}$ \\
\hline Delorme et al. (2019) & $\begin{array}{l}\text { Minimization of the maximum } \\
\text { number of workers }\end{array}$ & Straight MMAL & $\begin{array}{l}\text { Integer linear } \\
\text { programming and } \\
\text { dynamic } \\
\text { programming }\end{array}$ \\
\hline $\begin{array}{l}\text { Méndez-Vázquez \& } \\
\text { Nembhard (2019) }\end{array}$ & $\begin{array}{l}\text { Estimation of system's productivity } \\
\text { in four scenarios related to its } \\
\text { configuration }\end{array}$ & $\begin{array}{l}\text { Cellular manufacturing } \\
\text { system }\end{array}$ & Simulation \\
\hline
\end{tabular}


Mahdavi et al. (2010), and Soolaki (2012) studied workforce assignment problems in a dynamic CMS with reconfiguration, i.e., adding, removing and changing machines between cells. In these studies, workers can be removed from one cell and assigned to another cell in each time period. A similar production line configuration, in which workers can move from one station to another after completing a task in the MMAL, was considered in (Battaïa et al., 2015; Dolgui et al., 2018; Delorme et al., 2019). This movement changes the number of workers assigned to the tasks at stations, which, in turn, either increases or decreases corresponding task processing times. The objective was to find an optimal scheduling of worker moves among stations minimizing the number of workers while respecting the line takt time.

Most studies confirm that skilled walking workers improve the manufacturing system's performance and responsiveness. The reconfigurabity increases as well, as they shift productive capacity from one workplace to another in order to adapt it to the current situation in a production system.

In many researches, workers are assigned to stations based on their skill levels (Nakade \& Ohno, 1999; Wang et al., 2007; Nakade \& Nishiwaki, 2008; Al-Zuheri et al., 2013; Eğilmez et al., 2014; Mura \& Dini, 2016; Lian et al., 2018; Méndez-Vázquez \& Nembhard, 2019). Indeed, workers must be properly trained to perform multiple or complicated tasks efficiently. Learning by doing repetitive tasks usually reduces processing times, whereas long periods between two successive similar tasks lead to forgetting and increase processing times. The worker assignment taking into account learning and forgetting effects has drawn a certain attention from researchers (Anzanello \& Fogliatto, 2007; Thongsanit et al., 2010; Wang et al., 2013; Liu et al., 2016). 
In (Battini et al., 2007), the authors studied a semi-automated line, where workers perform tasks on a multi-turn rotation table. Sikora et al. (2017) provided some real case studies with human workers and robots, assignment restrictions, zoning constraints, tasks executed by machines and common tasks requiring at least two workers.

Bock et al. (2006) used workers' movement in a real time control of an MMAL to deal with disruptions caused by a worker's absence, material bottleneck, or machine breakdown, among others. Al-Zuheri et al. (2016) studied the impact of distances between workstations, number of stations, layout design and a workload assigning method on ergonomic measures including energy expenditure and walking time to standing position working time ratio. In (Yang et al., 2013) both tasks and workers are allowed to be reassigned to other stations when a change of the demand occurs. Battaïa et al. (2015) studied a workforce planning problem, in which workers are allowed to move between stations after finishing a task.

A combination of moving and temporary workers was considered by Francas et al. (2011). The authors proved that temporary workers always decrease the investment in regular workers. It was also shown that, in spite of a possible increase of investment on moving the regular workers due to a positive influence on labor utilization, moving workers enhance the efficiency of temporary workers. Thus, an industrial company may benefit from a right combination of temporary and moving workers.

\subsection{Bucket brigades}

Bartholdi \& Eisenstein (1996) introduced a self-balancing approach for flow shop manufacturing systems, called "bucket brigade" (BB). A bucket brigade is an organization of workforce movement, where the number of workers is lower than the number of stations and a worker follows 
the part from one station to the next until he/she meets his/her successor. Once a worker meets his/her successor, the successor takes over the work on the product, and the worker moves upstream to take over the part of his/her predecessor and so on. Bartholdi \& Eisenstein (1996) demonstrated that sequencing workers from the slowest to the fastest leads to a stable partition of work making the bucket brigade self-balancing.

In a survey paper, Bratcu \& Dolgui (2005) pointed out the main advantage of bucket brigades, namely, their adaptability to changing operational conditions like task times, product mix, spatial configuration modifications, etc. Moreover, their relatively easy implementation reduces the design and control effort, making the corresponding reconfiguration strategy popular among practitioners.

Despite the deterministic nature of the basic bucket brigade model, it can have a chaotic behavior that negatively influences the performance of an assembly line (Bartholdi et al., 2009). Indeed, the hand-offs can be unpredictable when workers are interrupted at any time or any position of the line. In the initial model the return velocity was considered as infinite. Song et al. (2011) studied bucket brigades with limited return velocities and analyzed their impact on the line's stability and productivity. They demonstrated that bucket brigades with the same return velocity are selfbalanced and that the line's productivity is directly proportional to the value of return velocity.

Lim (2011) introduced the concept of cellular bucket brigade (CBB), where the workers operate in aisles with production lines on both sides. A worker performs tasks at one side of the line moving in one direction, but when he/she reaches his/her successor, this worker executes tasks at the other side of the line, moving in the other direction. Thus, unproductive traveling times are reduced. Lim (2011) proposed simple rules for work sharing and a sufficient condition for self-balancing. 
Numerical experiments showed a $30 \%$ to $50 \%$ increase in throughput compared to the traditional bucket brigade model (Lim, 2012; 2017).

Table 5 contains recent papers on bucket brigades, where BB and CBB stand for bucket brigades and cellular bucket brigades, respectively.

Table 5. Studies considering bucket brigades

\begin{tabular}{|c|c|c|c|c|}
\hline Paper & Content or criteria & Type of system & $\begin{array}{l}\text { Solution } \\
\text { approach }\end{array}$ & $\mathrm{CBB} / \mathrm{BB}$ \\
\hline $\begin{array}{l}\text { Bartholdi \& Eisenstein } \\
\text { (1996) }\end{array}$ & $\begin{array}{l}\text { Modelling and performance } \\
\text { analysis of bucket brigades }\end{array}$ & $\begin{array}{l}\text { General manufacturing } \\
\text { systems }\end{array}$ & - & BB \\
\hline $\begin{array}{l}\text { Bartholdi et al. (1999, } \\
\text { 2001) }\end{array}$ & $\begin{array}{l}\text { Modelling and performance } \\
\text { analysis of bucket brigades } \\
\text { (deterministic/stochastic) }\end{array}$ & $\begin{array}{l}\text { General manufacturing } \\
\text { systems }\end{array}$ & - & BB \\
\hline $\begin{array}{l}\text { Bratcu \& Dolgui } \\
(2005)\end{array}$ & A survey on bucket brigades. & Assembly lines & - & $\mathrm{BB}$ \\
\hline Ahn \& Righter (2006) & $\begin{array}{l}\text { Analytical study of work } \\
\text { sharing between stations }\end{array}$ & $\begin{array}{l}\text { Straight general } \\
\text { manufacturing systems }\end{array}$ & - & BB \\
\hline Hytonen et al. (2008) & $\begin{array}{l}\text { Maximization of the workers' } \\
\text { utilization }\end{array}$ & Straight MMAL & $\begin{array}{l}\text { Discrete event } \\
\text { simulation }\end{array}$ & BB \\
\hline Bartholdi et al. (2009) & $\begin{array}{l}\text { Modelling and performance } \\
\text { analysis of bucket brigades } \\
\text { with chaotic behavior }\end{array}$ & $\begin{array}{l}\text { General manufacturing } \\
\text { systems }\end{array}$ & - & BB \\
\hline $\begin{array}{l}\text { Bratcu \& Dolgui } \\
\text { (2009) }\end{array}$ & $\begin{array}{l}\text { Finding a sufficient condition } \\
\text { for self-balancing. Building a } \\
\text { simulation model for general } \\
\text { complicated cases }\end{array}$ & $\begin{array}{l}\text { Dynamic general } \\
\text { manufacturing systems }\end{array}$ & $\begin{array}{l}\text { Analysis and } \\
\text { simulation }\end{array}$ & BB \\
\hline Lim \& Yang (2009) & $\begin{array}{l}\text { Maximization of the } \\
\text { throughput }\end{array}$ & $\begin{array}{l}\text { General manufacturing } \\
\text { system }\end{array}$ & $\begin{array}{l}\text { Heuristic } \\
\text { (simulation) }\end{array}$ & BB \\
\hline Quintana et al. (2009) & $\begin{array}{l}\text { Maximization of the } \\
\text { machine availability and } \\
\text { utilization }\end{array}$ & $\begin{array}{l}\text { General manufacturing } \\
\text { system }\end{array}$ & Simulation & BB \\
\hline Koo (2009) & $\begin{array}{l}\text { Maximization of the workers' } \\
\text { productivity }\end{array}$ & Order picking system & Simulation & BB \\
\hline Wang et al. (2009) & $\begin{array}{l}\text { Minimization of in-process } \\
\text { waiting times }\end{array}$ & U-shape MMAL & $\begin{array}{l}\text { Simulation and } \\
\text { mathematical } \\
\text { modelling }\end{array}$ & BB \\
\hline Wang et al. (2010) & $\begin{array}{l}\text { Minimization of in-process } \\
\text { waiting and traveling times }\end{array}$ & Assembly line & $\begin{array}{l}\text { Mathematical } \\
\text { modelling }\end{array}$ & BB \\
\hline Song et al. (2011) & $\begin{array}{l}\text { Maximization of } \\
\text { productivity and production } \\
\text { stability }\end{array}$ & $\begin{array}{l}\text { General manufacturing } \\
\text { system }\end{array}$ & Heuristic & BB \\
\hline $\begin{array}{l}\text { Villalobos et al. } \\
\text { (2011) }\end{array}$ & $\begin{array}{l}\text { Minimization of the labor } \\
\text { turnover }\end{array}$ & $\begin{array}{l}\text { Serial assembly lines } \\
\text { with workforce } \\
\text { learning effects }\end{array}$ & $\begin{array}{l}\text { Modified work } \\
\text { sharing }\end{array}$ & BB \\
\hline Webster et al. (2012) & $\begin{array}{l}\text { Maximization of the } \\
\text { throughput }\end{array}$ & Order picking line & $\begin{array}{l}\text { Discrete event } \\
\text { simulation }\end{array}$ & BB \\
\hline Lim et al. (2011) & $\begin{array}{l}\text { Minimization of the } \\
\text { unproductive travel. Simple }\end{array}$ & $\begin{array}{l}\text { Generalized assembly } \\
\text { line }\end{array}$ & $\begin{array}{l}\text { Numerical } \\
\text { simulation }\end{array}$ & $\mathrm{CBB}$ \\
\hline
\end{tabular}




\begin{tabular}{|c|c|c|c|c|}
\hline & $\begin{array}{l}\text { rules leading to the line's } \\
\text { self-balancing }\end{array}$ & & & \\
\hline $\operatorname{Lim}(2012)$ & $\begin{array}{l}\text { Minimization of the } \\
\text { unproductive travel. Simple } \\
\text { rules leading to the line's } \\
\text { self-balancing }\end{array}$ & Order picking line & $\begin{array}{l}\text { Numerical } \\
\text { simulation }\end{array}$ & CBB \\
\hline Sriram et al. (2014) & $\begin{array}{l}\text { Maximization of the } \\
\text { throughput }\end{array}$ & $\begin{array}{l}\text { U-shape cellular } \\
\text { manufacturing system }\end{array}$ & $\begin{array}{l}\text { Discrete event } \\
\text { simulation }\end{array}$ & CBB \\
\hline Lim \& Wu (2014) & $\begin{array}{l}\text { Minimization of the } \\
\text { unproductive travel. Simple } \\
\text { rules leading to the line's } \\
\text { self-balancing }\end{array}$ & $\begin{array}{l}\text { Generalized assembly } \\
\text { line }\end{array}$ & $\begin{array}{l}\text { Numerical } \\
\text { simulation }\end{array}$ & CBB \\
\hline $\operatorname{Lim}(2017)$ & $\begin{array}{l}\text { Minimization of the } \\
\text { unproductive travel. Impact } \\
\text { of hand-off times on the CBB } \\
\text { performance }\end{array}$ & $\begin{array}{l}\text { Generalized assembly } \\
\text { line }\end{array}$ & $\begin{array}{l}\text { Numerical } \\
\text { simulation }\end{array}$ & CBB \\
\hline Zhou et al. (2017) & $\begin{array}{l}\text { Minimization of the } \\
\text { unproductive travel }\end{array}$ & $\begin{array}{l}\text { Generalized assembly } \\
\text { line }\end{array}$ & $\begin{array}{l}\text { Mathematical } \\
\text { modelling and } \\
\text { simulation }\end{array}$ & $\mathrm{CBB}$ \\
\hline
\end{tabular}

Sriram et al. (2014) considered a bucket brigade approach in a U-shape assembly line with buffers.

They proposed a new control protocol for bucket brigades. By using a discrete events simulation and an optimization model, the authors determined optimal buffer locations and buffer control levels associated with each worker maximizing the line throughput. A buffer level is the amount of excess production capacity in a production line that is included to ensure that production goals are met in the event of downtime. Lim \& Wu (2014) proposed some simple cellular bucket brigade rules to coordinate workers in a U-shape assembly line with stations in which at most one worker is allowed to operate at a station. The goal was to maximize the productivity of the line. The simulation results show that the number of stations has a critical impact on the performance of a cellular bucket brigade.

\subsection{Cross-trained workers}

A cross-trained worker is a worker able to perform multiple tasks in various locations of a manufacturing system when needed (Ebeling \& Lee, 1994). Compared to walking or bucket brigade workers, who are initially trained to perform multiple tasks and whose movement is 
planned, cross-trained workers are specialized on specific tasks but also trained to perform other tasks in case of an unplanned necessity. Such unplanned necessities include an ill operator, a change of product mix, or a change in the demand of specific products. Workers' cross-training improves their understanding of the whole production process and tends to increase the overall quality of the manufactured products.

A cross-trained worker's timely response to unplanned situations enhances the flexibility of a manufacturing system. On the other hand, cross-training is costly, and it can increase the production time. To mitigate these shortcomings, several strategies for efficient cross-training were introduced. In the chain cross-training strategy (Inman et al., 2004), workers are trained to execute a secondary task, and tasks are allocated to the workers in a chain. For example, worker A performs tasks 1 and 2, worker B executes tasks 2 and 3, and so on, where the latter task for each worker is the secondary task. Hopp et al. (2004) proposed two other strategies, namely, cherry-picking and skill chaining. In cherry-picking, cross-trained workers assist their colleagues in a bottleneck station to increase the system's throughput. Such strategy implies a higher investment in workers' cross-training. Skill chaining reduces cross-training costs since only workers from an adjacent station assist directly at the bottleneck station. Others assist indirectly by taking part of the work of the following or preceding station. More details on skill chaining with cross-trained workforce are presented in (Tekin et al., 2002). A summary of the studies on problems with cross-trained workers is given in Table 6.

Table 6. Studies considering cross-trained workers

\begin{tabular}{|l|l|l|l|}
\hline Paper & Criteria & Type of system & Solution approach \\
\hline $\begin{array}{l}\text { Ebeling \& Lee } \\
(1994)\end{array}$ & Maximization of the total profit & Straight MMAL & $\begin{array}{l}\text { Integer linear } \\
\text { programming }\end{array}$ \\
\hline $\begin{array}{l}\text { Vairaktarakis \& } \\
\text { Winch (1999) }\end{array}$ & $\begin{array}{l}\text { Minimization of the number of } \\
\text { workers and cross-training cost }\end{array}$ & Straight MMAL & $\begin{array}{l}\text { Branch-and-bound and } \\
\text { heuristics }\end{array}$ \\
\hline
\end{tabular}




\begin{tabular}{|c|c|c|c|}
\hline $\begin{array}{l}\text { McCreery \& } \\
\text { Krajewski (1999) }\end{array}$ & Maximization of performance & U-shape MMAL & Heuristic \\
\hline $\begin{array}{l}\text { ElMaraghy et al. } \\
(2000)\end{array}$ & Minimization of the mean flow time & Job shop & Genetic algorithm \\
\hline Norman et al. (2002) & $\begin{array}{l}\text { Maximization of the effectiveness } \\
\text { including productivity, product } \\
\text { quality, training costs }\end{array}$ & $\begin{array}{l}\text { Cellular } \\
\text { manufacturing system }\end{array}$ & $\begin{array}{l}\text { Mixed integer } \\
\text { programming }\end{array}$ \\
\hline $\begin{array}{l}\text { Campbell \& Diaby } \\
(2002)\end{array}$ & $\begin{array}{l}\text { Maximization of the utility of } \\
\text { workers in departments }\end{array}$ & $\begin{array}{l}\text { General service } \\
\text { system }\end{array}$ & Heuristic \\
\hline Inman et al. (2004) & Minimization of the cost of workers & $\begin{array}{l}\text { Straight single-model } \\
\text { assembly line }\end{array}$ & $\begin{array}{l}\text { Heuristic (chain cross- } \\
\text { training) }\end{array}$ \\
\hline Hopp et al. (2004) & $\begin{array}{l}\text { Maximization of throughput for a } \\
\text { fixed work-in-process and finding } \\
\text { the necessary amount of work-in- } \\
\text { process for the desired throughput }\end{array}$ & $\begin{array}{l}\text { General manufacturing } \\
\text { system }\end{array}$ & $\begin{array}{l}\text { Heuristic (cherry } \\
\text { picking and skill } \\
\text { chaining) }\end{array}$ \\
\hline Bokhorst et al. (2004) & Maximization of the productivity & Job shop & Simulation \\
\hline Slomp et al. (2005) & $\begin{array}{l}\text { Minimization of the training and } \\
\text { operating cost }\end{array}$ & $\begin{array}{l}\text { Cellular } \\
\text { manufacturing system }\end{array}$ & Integer programing \\
\hline Sennott et al. (2006) & $\begin{array}{l}\text { Minimization of the total cost and } \\
\text { maximization of the workforce } \\
\text { utilization }\end{array}$ & $\begin{array}{l}\text { General manufacturing } \\
\text { system }\end{array}$ & $\begin{array}{l}\text { Approximating } \\
\text { sequence method }\end{array}$ \\
\hline Winch et al. (2007) & $\begin{array}{l}\text { Minimization of the number of } \\
\text { workers }\end{array}$ & Straight MMAL & $\begin{array}{l}\text { Branch-and-bound and } \\
\text { heuristics }\end{array}$ \\
\hline $\begin{array}{l}\text { Sayin \& Karabati } \\
(2007)\end{array}$ & $\begin{array}{l}\text { Maximization of the department } \\
\text { utility (function of the labor } \\
\text { shortage) and the total skill } \\
\text { improvement }\end{array}$ & $\begin{array}{l}\text { Generalized } \\
\text { manufacturing or } \\
\text { service system }\end{array}$ & $\begin{array}{l}\text { Simulation, mixed- } \\
\text { integer programming } \\
\text { with piecewise linear } \\
\text { approximation }\end{array}$ \\
\hline Fowler et al. (2008) & $\begin{array}{l}\text { Minimization of the workforce } \\
\text { related cost }\end{array}$ & $\begin{array}{l}\text { General manufacturing } \\
\text { system }\end{array}$ & $\begin{array}{l}\text { Heuristics and genetic } \\
\text { algorithm }\end{array}$ \\
\hline Yue et al. (2008) & $\begin{array}{l}\text { Maximization of the system's } \\
\text { efficiency }\end{array}$ & Job shop & Simulation \\
\hline Kaku et al. (2008) & $\begin{array}{l}\text { Maximization of the productivity, } \\
\text { minimization of the inventory and } \\
\text { stock outs }\end{array}$ & $\begin{array}{l}\text { U-shape MMAL and } \\
\text { Cellular } \\
\text { manufacturing system }\end{array}$ & $\begin{array}{l}\text { Heuristic (human- } \\
\text { factor-based training } \\
\text { approach) and } \\
\text { simulation }\end{array}$ \\
\hline Davis et al. (2009) & $\begin{array}{l}\text { Minimization of the workload } \\
\text { imbalance }\end{array}$ & Job shop & Simulation \\
\hline $\begin{array}{l}\text { Aryanezhad et al. } \\
(2009)\end{array}$ & $\begin{array}{l}\text { Minimization of the total cost } \\
\text { including production, hiring, firing, } \\
\text { and training costs }\end{array}$ & $\begin{array}{l}\text { Dynamic cellular } \\
\text { manufacturing system }\end{array}$ & Linear programming \\
\hline $\begin{array}{l}\text { Bokhorst \& Gaalman } \\
\text { (2009) }\end{array}$ & Maximization of the productivity & Job shop & Simulation \\
\hline $\begin{array}{l}\text { Satoglu \& Suresh } \\
(2009)\end{array}$ & $\begin{array}{l}\text { Minimization of cross-training, } \\
\text { hiring, firing, and over-assignment } \\
\text { of workers to more than one cell }\end{array}$ & $\begin{array}{l}\text { Hybrid (adapted both } \\
\text { to high/stable and } \\
\text { low/sporadic demand) } \\
\text { cellular manufacturing } \\
\text { system }\end{array}$ & Goal programming \\
\hline Campbell (2011) & $\begin{array}{l}\text { Maximization of the workers' utility } \\
\text { in the departments }\end{array}$ & $\begin{array}{l}\text { General service } \\
\text { system }\end{array}$ & $\begin{array}{l}\text { Two-stage stochastic } \\
\text { approach }\end{array}$ \\
\hline Easton $(2011,2014)$ & $\begin{array}{l}\text { Minimization of the labor cost, } \\
\text { maximization of the service level }\end{array}$ & $\begin{array}{l}\text { General service } \\
\text { system }\end{array}$ & $\begin{array}{l}\text { Two-stage stochastic } \\
\text { approach }\end{array}$ \\
\hline $\begin{array}{l}\text { Kim \& Nembhard } \\
\text { (2013) }\end{array}$ & $\begin{array}{l}\text { Minimization of the number of } \\
\text { workers }\end{array}$ & Parallel MMAL & Data mining technique \\
\hline
\end{tabular}




\begin{tabular}{|l|l|l|l|}
\hline Xu et al. (2015) & $\begin{array}{l}\text { Minimization of the total } \\
\text { workforce-related cost and } \\
\text { maximization of the customer } \\
\text { satisfaction }\end{array}$ & $\begin{array}{l}\text { General service } \\
\text { system }\end{array}$ & $\begin{array}{l}\text { Binary programing and } \\
\text { non-dominated sorting } \\
\text { genetic algorithm }\end{array}$ \\
\hline Yang \& Gao (2016) & $\begin{array}{l}\text { Minimization of the number of skill } \\
\text { zones (stations) }\end{array}$ & Straight MMAL & Branch-and-bound \\
\hline Wu et al. (2018) & $\begin{array}{l}\text { Minimization of the training cost, } \\
\text { maximization of the workload } \\
\text { balance }\end{array}$ & $\begin{array}{l}\text { Cellular } \\
\text { manufacturing system }\end{array}$ & $\begin{array}{l}\text { Particle swarm } \\
\text { optimization and } \\
\text { artificial bee colony }\end{array}$ \\
\hline Chu et al. (2019) & $\begin{array}{l}\text { Minimization of the costs related to } \\
\text { the workers' training, assignment, } \\
\text { and workload imbalance }\end{array}$ & $\begin{array}{l}\text { Cellular } \\
\text { manufacturing system }\end{array}$ & $\begin{array}{l}\text { Adaptive memetic } \\
\text { differential search } \\
\text { algorithm }\end{array}$ \\
\hline
\end{tabular}

The positive impact of using cross-trained workers on the production system's performance was proved in numerous studies. For example, in Sayin \& Karabati (2007), the authors proposed a simulation model to analyze the impact of some parameters on the utility and skill improvement. These parameters include the number of workers, departments, demand for workers, learning speed, demand variation, etc. The authors suggest that cross-training and skill improvement lead to higher system's productivity. Davis et al. (2009) showed that an extensive cross-training improves the performance under high workload variation conditions. However, in the case of insufficient capacity of equipment in a job shop manufacturing system, additional training expenses are not justified by the marginal improvement related to cross-training. The impact of cross-trained workers' learning and forgetting effects on the performance of manufacturing systems were also investigated by (McCreery \& Krajewski, 1999; Kim \& Nembhard, 2013; Chu et al., 2019).

Several studies on using cross-trained workforce in dual resource constrained (DRC) production systems were conducted, for example in (Yue et al., 2008; Bokhorst \& Gaalman, 2009; Bokhorst et al., 2004; Hottenstein \& Bowman, 1998; Elmaraghy et al., 2000; Davis et al., 2009; Satoglu \& Suresh, 2009; Xu et al., 2015). DRC system is a manufacturing system, which is not only constrained by machine capacity, but also by workforce capacity. Cross-trained workforce is also 
largely used in CMS (Slomp et al., 2005; Kaku et al., 2008; Aryanezhad et al., 2009; Wu et al., 2018; Chu et al., 2019).

\section{Analysis of workforce reconfiguration strategies in different manufacturing systems and promising research directions}

Several workforce reconfiguration strategies, helping to improve the manufacturing system's adaptability and resilience are described in the previous section. This section has two goals. The

first goal is to overview the existing literature on workforce planning and assignment and to clarify the importance of workforce reconfiguration strategies for different types of manufacturing systems. The second goal is to analyze workforce reconfiguration strategies by highlighting their advantages and challenges and to provide promising research directions.

4.1. Analysis of the research on workforce reconfigurability for different types of manufacturing systems

This subsection reviews the literature on different types of manufacturing systems and certifies the relative significance of workforce reconfiguration strategies for each of them. It is interesting to see how the five workforce reconfiguration strategies, have been studied across different types of manufacturing systems: dedicated, flexible, cellular, and reconfigurable manufacturing systems. Figure 2 shows the number of articles in refereed journals per year related to each workforce reconfiguration strategy, whereas Figure 3 gives the number of papers based on both the workforce reconfiguration strategies and manufacturing system's types. 


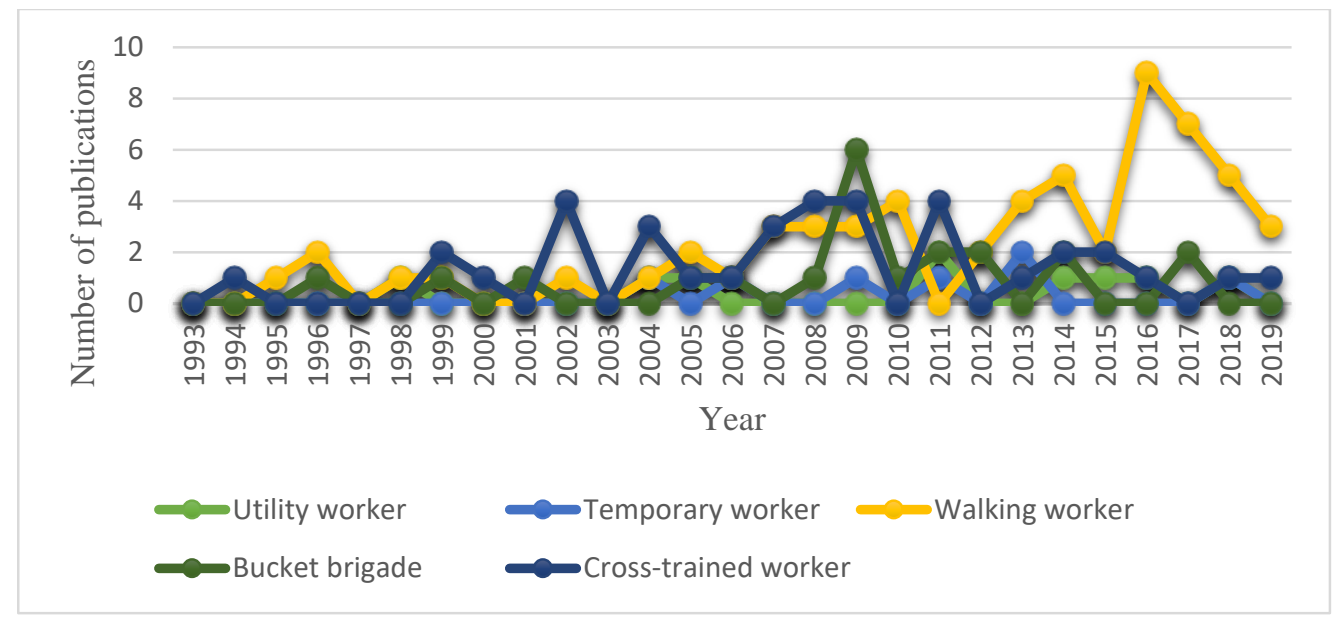

Figure 2. The number of articles per year related to each workforce reconfiguration strategy

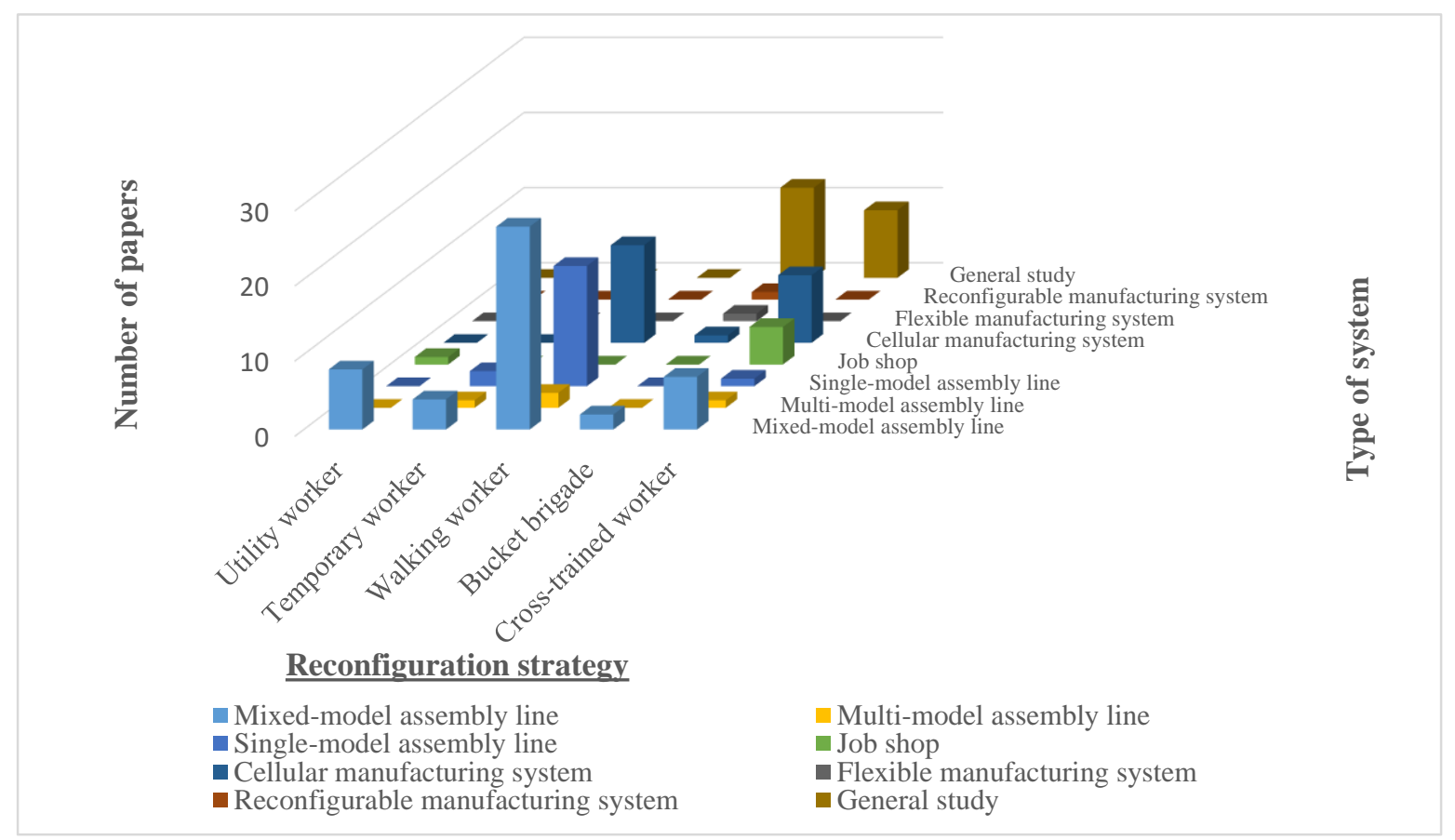

Figure 3. The number of papers based on both workforce reconfiguration strategy and manufacturing system's type

These figures indicate that most of the studies consider mixed-model manual assembly lines and emphasize the importance of utility, walking and cross-trained workers in the system's reconfigurability. 


\subsubsection{Dedicated Manufacturing System and Mixed- and Multi-model Assembly Lines}

A large number of studies exist on workforce assignment in a DMS, see for example (Sungur \& Yavuz, 2015; Lai et al., 2019). Several researchers studied workforce assignment for a singlemodel assembly line (Nakade \& Ohno, 1999; Miralles et al., 2008; Moreira \& Costa, 2009; Chaves et al., 2007; Anzanello \& Fogliatto, 2007; Thongsanit et al., 2010; Mura \& Dini, 2016). In contrast, due to the fact that only one product can be produced by a DMS, there are only few studies regarding workforce reconfigurability (e.g., Corominas et al., 2008; Moreira \& Costa, 2009; Stadnicka et al., 2017; Gebennini et al., 2018). On the other hand, a large body of literature is dedicated to workforce assignment problems related to mixed/multi-model assembly lines (e.g., Battaïa et al., 2015; Delorme et al., 2019), since such lines are usually manual. In most cases, see Figure 2, the line's adaptability is achieved by walking workers, who, upon completion of a task, can be assigned to another task at another station. On the one hand, walking workers allow to have a necessary minimal amount of workers to accomplish the task and therefore keep the production going. On the other hand, this strategy can decrease the task's processing time and consequently increase the line's productivity. In many studies, the number of workers and workforce-related costs (e.g. cost of temporary workers' hiring, cross-training cost) are a part of the problem's criterion. In such case, the cycle time criterion is usually replaced by the corresponding constraint, limiting the value of a station time.

\subsubsection{Cellular Manufacturing System}

A CMS can be viewed as a collection of several assembly lines (cells), each of which is designed to process only a specific set of products. Thus, a CMS represents a mixture of flow and job shop systems. Compared to a static situation, where the demand volume and product mix are known, a 
multi-period problem with changing demand volume and product mix requires a CMS to be robust and adaptive. Historically, the re-assignment of machines between cells (adding, removing and swapping) was the first type of CMS's reconfiguration, see for example (Safaei et al., 2008; Papaioannou \& Wilson, 2010). In a CMS involving workers, cells quite often have a U-shaped layout, allowing workers assigned to a cell to move from one station (machine) to another in a short time (Schrader \& Elshennawy, 2000). In a quickly changing dynamic environment, the adaptability of a CMS can be increased by using the workforce reconfiguration strategies. While many studies on multi-period dynamic CMS with workforce considered the possibility of workers' firing (Satoglu \& Suresh, 2009; Mahdavi et al., 2010), some of the workforce reconfiguration strategies can provide an alternative, in which the number of workers do not change. Thus, utility, moving or cross-trained workers can travel between cells, providing necessary skills and manpower when and where needed without demoralizing layoffs related to a sudden drop in demand, for example. On the other hand, training costs incurred by these strategies can be relatively high. An adequate trade-off between using these strategies and changing the number of workers should be made.

\subsubsection{Flexible Manufacturing System}

In general, the literature on workforce in FMS is poor, since a long time they were considered as fully automated systems, mainly composed of CNC machines and robots. It is extremely hard to find even the keyword "workforce" or "workers" in the FMS-related literature, which is itself quite scarce. Sometimes researchers describe another system, using the term FMS. For example, Cronin et al. (2019) call an assembly line an FMS. Bortolini et al. (2019) use the term FMS to denote a CMS. 
Lee at al. (2020) used the term FMS in its conventional meaning. The authors considered workers, who load parts of different type on a pallet, which is then released into the system, composed of numerical control machines and the central buffer. The workers also unload the pallets. The studied problem consists in minimizing the total tardiness, taking into account, among other constraints, workers' availability times.

Due to its complexity, an FMS requires the presence of a highly skilled personnel to control the production process (Mehrabi et al., 2002). It comes at a cost and urges a company to reduce the number of such operators as much as possible, taking into account the high cost of an FMS itself. Therefore, it can be concluded that the scope of workforce reconfiguration strategies' application to an FMS was extremely small. Nevertheless, the new tendencies consist in adding workers into FMS to decrease the cost and increase the reliability, thus the workforce planning problems also concern FMS.

\subsubsection{Reconfigurable Manufacturing System}

Workforce planning in RMS have been generally ignored by the researchers. Only a few papers shed light on this aspect. Askin \& Huang (1997) developed two integer programming models to assign workers and determine their individual training programs. Peruzzini \& Pellicciari (2017) claimed that in order to create an effective smart factory context (e.g., a FMS or a RMS), human performance should be taken into account and managed in the most efficient way. In the paper (Gyulai et al., 2017), the authors proposed a method to minimize the number of workers in a reconfigurable assembly system with constraint programming and genetic algorithms. Harari et al. (2018) took into account the human resource as a component of the design process of flexible and reconfigurable assembly systems. Andersen et al. (2018) demonstrated that convertibility, i.e. 
ability to change the functionality of a system to meet new production requirements, is easier to implement in a high-level manual production than in a less manual manufacturing system. Noticeably, convertibility is one of the main characteristics of RMS (Koren et al., 1999). A flexible workforce increases the convertibility of the manufacturing system.

The following differences between FMS and RMS lead to consider that workforce planning problems in RMS represent a promising research avenue. Firstly, RMS is less automated than FMS. Secondly, in contrast to the numerical control flexibility of FMS, the main principle of RMS is a physical reconfiguration of resources. Finally, RMSs are mixed systems with CNC machines, reconfigurable achines tools (RMT), traditional machines, collaborative robots (cobots) and reconfigurables workstations where workers play an important role. Workforce is one of the main resources in an RMS, and the principles of RMS foster its reconfiguration. Surprisingly, there are only few studies on workforce reconfiguration in RMS. In contrast to machines, human workers are naturally flexible and able to perform a task, which is not necessarily related to the scope of their predestination. A human worker can handle a non-standard situation, in which a machine would definitely fail, because, in case of such situation, it has no predetermined procedure to follow. Even though a recent progress in artificial intelligence may mitigate this flow, the aspect of cost of such smart and adaptive machines cannot be ignored. Usually the worker's training required to improve or acquire certain skills and, therefore, increase his or her flexibility, is cheaper than building a new functionality of a machine. Considering these factors, an application of workforce reconfiguration strategies in RMS represent an interesting research direction for future studies.

In contrast to the large number of studies on workforce planning in single/mixed/multi model assembly lines and CMS, the corresponding literature related to FMS and RMS is poor. Figure 4 
positions different manufacturing systems according to two factors: the amount of literature associated with workforce reconfiguration and the importance of system's reconfigurability.

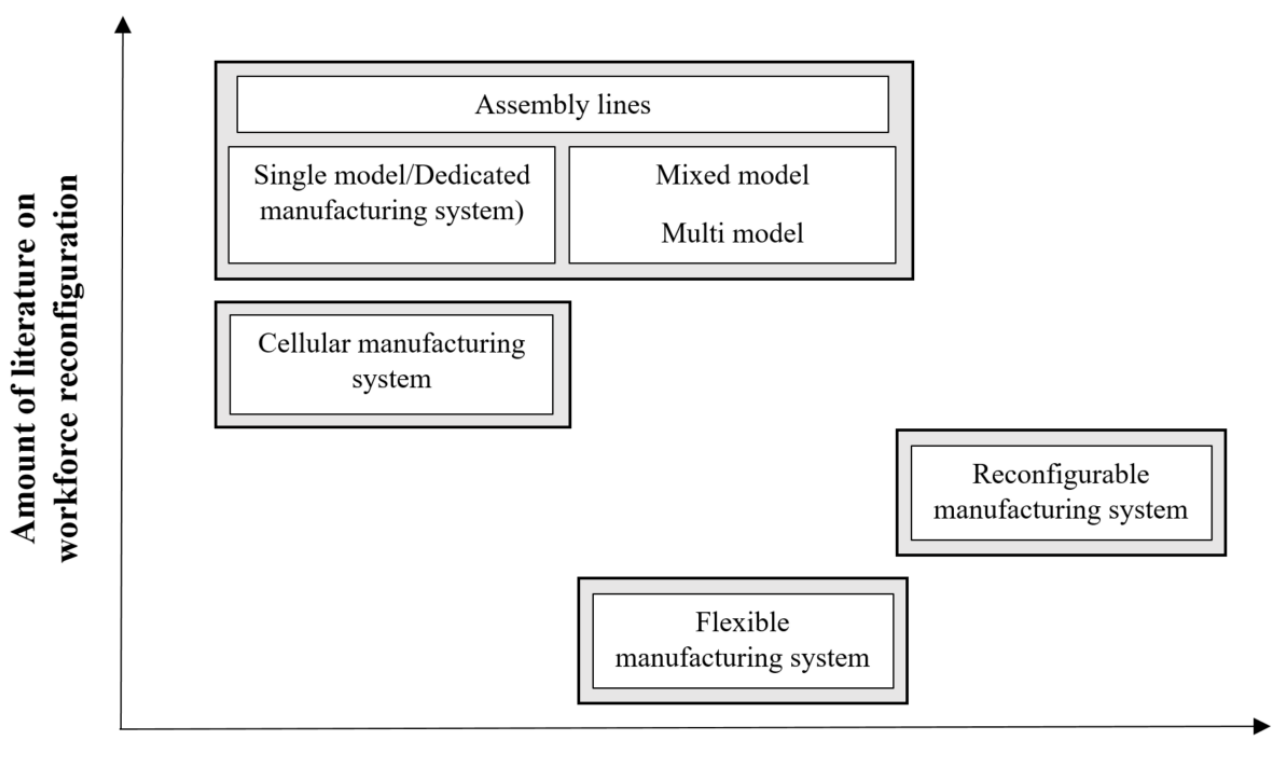

Importance of system's reconfiguration

Figure 4. Compliance of the workforce reconfiguration related studies to the importance of system's reconfiguration for different manufacturing systems

Figure 4 shows the mismatch between the high importance of reconfigurability for an RMS and the scarcity of corresponding studies related to workforce reconfiguration, thus emphasizing an interest in such research. In order to enhance the contrast and logical connection between different workforce reconfiguration strategies and the different types of manufacturing system, Table 7 presents them with regard to the existing literature $(\times)$ and the open issues for future studies (?). The papers existing the literature have been presented before, and several future research directions are proposed to be taken into account in future researches. In the current state, FMSs and RMSs use only equipment flexibility and re-configurability. For FMSs, this can be explained by the fact that they were considered in the past as fully automated systems. Nevertheless, the last tendencies in industry consist in adding human workers into the FMS. For RMS, this is even more important 
and crucial, because RMSs are mixed systems with CNC machines, RMT, traditional machinestools, cobots and reconfigurable workstations, etc. The study of reconfigurability of RMS, based on both machine and workforce reconfigurations is a challenging research issue. The advantages of workforce flexibility and how workforce flexibility can improve the overall adaptability of production systems in the case of FMS and RMS are not studied in literature and can be new promising research directions.

Table 7. Current state of applying workforce reconfiguration strategies to different manufacturing systems

\begin{tabular}{|l|c|c|c|}
\hline & $\begin{array}{l}\text { Dedicated manufacturing } \\
\text { system and mixed/multi-model } \\
\text { assembly line }\end{array}$ & $\begin{array}{l}\text { Cellular manufacturing } \\
\text { system }\end{array}$ & $\begin{array}{c}\text { Flexible and } \\
\text { reconfigurable } \\
\text { manufacturing system }\end{array}$ \\
\hline Utility workers & $\times$ & $?$ & $?$ \\
\hline Temporary workers & $\times$ & $\times$ & $?$ \\
\hline Walking workers & $\times$ & $\times$ & $?$ \\
\hline Bucket brigades & $\times$ & $\times$ & $?$ \\
\hline Cross-trained workers & & $?$ \\
\hline
\end{tabular}

\subsection{Analysis of workforce reconfiguration strategies and promising research directions}

Numerous studies show that workforce reconfiguration strategies have a positive impact on the manufacturing system's efficiency. For instance, the use of utility workers reduces production stoppages, and it decreases the stocks of unfinished goods. Temporary workers help coping with sudden demand increases. Walking workers allow to adjust capacity to different combinations of unfinished goods located in a manufacturing system at a certain moment of time. Bucket brigades provide an easy-to-implement worker assignment rule able to adapt to fluctuating operational conditions. Cross-trained workers apply their broad skills in order to react to unplanned situations. 
However, the use of such strategies comes at a cost and may lead to certain side effects like the increased workers' stress and over-load. Using temporary or cross-trained workers may bring several advantages for a company, such as an increased productivity and responsiveness (Stratman et al., 2004; Sayin \& Karabati, 2007). However, the implementation of these strategies incurs the increased cost of hiring and training, which may not necessarily be reasonable. The use of walking workers increases the input of a manufacturing system, but an excessive overload of such workers may lead to a fatigue and stress, which, in turn, negatively affects the system's performance. In fact, manufacturers need to properly trade-off advantages against the disadvantages caused by these strategies. For example, (Slopm et al., 2005) try to find the best possible trade-off between the operating costs of a manufacturing cell, related to the workload of the most charged worker, and the cross-training costs.

Most studies on manufacturing systems with workforce consider the criteria of efficiency, throughput and costs. Ergonomic side effects such as fatigue, injuries, absenteeism and stress, caused by overload, frequent task change, movement or inadequate workspace organization, are not yet sufficiently studied. However, this issue becomes more and more relevant in the recent publications on workforce planning. These studies take into account workers' fatigue through repetitive movements (Asensio-Cuesta et al., 2012), metabolic energy expense (Al-Zuheri et al., 2016), risks and psychological costs of the heavy tasks (Gebennini et al., 2018). Otto \& Battaïa (2017) surveyed the literature on optimization methods for assembly line balancing and job rotation scheduling, which takes into account physical ergonomic risks. In those studies, ergonomic risks are either included in the objective function or represented as constraints. This survey might be useful for the future studies in this direction. Besides, future studies on ergonomic 
risks in workforce planning and assignment could benefit from consideration of the workers' cognitive load and its measuring methods.

Specific industrial situations favor a certain workforce reconfiguration strategy. For example, using temporary workers can be useful for a company that produces seasonal products (Corominas et al., 2008), while bucket brigades, thanks to their self-balancing nature and relatively easy implementation, are especially useful in case of short lifecycle products manufacturing (Bartholdi \& Einstein, 1996). At the same time, these strategies are closely connected to each other in practice. For instance, bucket brigades and cross-trained workers can be seen as a kind of walking workers. Workers' movement in bucket brigades follows the constant simple rules, while cross-trained workers move from one station to another in case of necessity (Ebeling \& Lee, 1994). In fact, a proper combination of strategies may provide better results than implementing only one. For example, Cevikcan \& Durmusoglu (2011) and Francas et al. (2011) found the benefits of using moving workers in combination with temporary and utility workers.

The five workforce reconfiguration strategies and two possible research directions, ergonomics aspects and strategies' combination, can be also applied to a so-called hybrid human-robot collaborative system. In fact, each type of manufacturing systems, although with a much lesser degree for an FMS, can employ robots and create a human-robot collaboration environment.

Researchers studying operations management problems have paid a little attention to such hybrid systems. However, using collaborative robots, so-called cobots, helps manufacturing systems to improve their efficiency combining the advantages of workforce (e.g. flexibility, creativity, trainability, intelligence) and the advantages of robots, such as force, accuracy, tirelessness and speed (Hashemi-Petroodi et al., 2020). There are several ways of interaction between robots and 
humans in a hybrid system that affect the control, balancing and planning of a manufacturing system: independent, simultaneous, sequential, and supportive (El Zaatari et al., 2019). A heavy task, which is dangerous for a worker, can be performed by a robot, while workers can perform certain delicate tasks requiring less force but more flexibility. In order to avoid the monotony of habitual operations, certain safe tasks can be from time to time performed or assisted by workers. In modern quickly changing market conditions, hybrid human-robot manufacturing systems must be adaptive, which requires a high degree of reconfigurability. Such a reconfiguration does not only concern the robots but also the workforce, and the use of utility, temporary, cross-trained, moving workers or bucket brigades would allow a timely and efficient adjustment of resources. The specificity of workforce reconfiguration strategies in such system consists in the consideration of inevitable human-robot interaction, and it opens some promising research directions.

Another future research opportunity consists in investigating the impact of new technologies, which help to improve the interaction between workers, machines and robots. For example, such technologies and communication modes as smart devices, cameras, sensors, teleoperation, message exchange and augmented reality facilitate the interaction between human operators and robots and makes the manufacturing environment safer.

\section{Conclusion}

The rise of mass customization and shortening product lifecycles drive industrial companies to employ manufacturing systems with a high level of reconfigurability needed to adapt to quickly changing market conditions. The core interest of workforce planning lies in the workforce's ability to enhance the manufacturing system's reconfigurability. The current paper provides a literature review of the research related to workforce reconfiguration. The literature is classified according 
to five workforce reconfiguration strategies: the use of utility, temporary, moving, cross-trained workers and bucket brigades. These strategies are presented in the context of different manufacturing system types: dedicated, flexible, cellular, reconfigurable manufacturing systems and assembly lines.

The review ascertains that most of the studies are dedicated to manual assembly lines, since they are often used in practice. The number of papers with the keyword "assembly line" significantly exceeds the one with the keywords "flexible", "cellular" or, to the less extent, "reconfigurable" manufacturing systems. However, they are not mutually exclusive. For example, an assembly line that has a customized flexibility, changeable workstation structures, product variety and reconfigurable workforce, can be considered as a reconfigurable manufacturing system.

The literature analysis reveals a lack of study on workforce reconfiguration in reconfigurable manufacturing systems. In spite of a significant amount of literature on reconfigurable machines and tools, a combined approach integrating machines' and workers' reconfiguration has not been studied yet. Unlike a flexible manufacturing system, a reconfigurable manufacturing system is not fully automated. Therefore, a joint analysis of machine and workforce reconfigurations in a reconfigurable manufacturing system can enhance its adaptability and robustness.

Several major avenues for future research are identified. The first consists in the consideration of ergonomic aspect. The second suggests applying a proper combination of several workforce strategies. The third calls to consider workforce strategies in an emerging human-robot collaborative environment. The fourth consists in studying the influence of the new technologies, such as smart devices, cameras, sensors, teleoperation, message exchange and augmented reality, on a manufacturing system employing both automated resources and human workers. 


\section{Acknowledgment}

The authors of this paper would like to thank the Region Pays de la Loire, France

(www.paysdelaloire.fr) for financial support of this study.

\section{References}

Ahn, H.-S., \& Righter, R. (2006). Dynamic load balancing with flexible workers. Advances in Applied Probability, 38(3), 621-642.

Ahn, H. S., Duenyas, I., \& Lewis, M. E. (2002). Optimal control of a two-stage tandem queuing system with flexible servers. Probability in the Engineering and Informational Sciences, 16(4), 453-469.

Akagi, F., Osaki, H., \& Kikuchi, S. (1983). A method for assembly line balancing with more than one worker in each station. International Journal of Production Research, 21(5), 755-770.

Al-Zuheri, A., Luong, L., \& Xing, K. (2010). An integrated design support methodology for walking worker assembly lines. In Proceedings of the International Multi-conference of Computer and Engineering Scientists (IMECS 2010), Hong Kong, International Association of Engineers vol. III, pp. 1612-1617, March 17 - 19, 2010.

Al-Zuheri, A., Luong, L., \& Xing, K. (2013). Prediction and analysis impact of operational design of a manual assembly system with walking workers on performance. International Journal of Computer Integrated Manufacturing, 26(6), 540-560.

Al-Zuheri, A., Luong, L., \& Xing, K. (2014). Using simulation in verification of a mathematical model for predicting the performance of manual assembly line occupied with flexible workforce. International Journal of Simulation and Process Modelling, 9(4), 270-284.

Al-Zuheri, A., Luong, L., \& Xing, K. (2016). Developing a multi-objective genetic optimisation approach for an operational design of a manual mixed-model assembly line with walking workers. Journal of Intelligent Manufacturing, 27(5), 1049-1065.

Aljuneidi, T., \& Bulgak, A. A. (2016). Design of cellular manufacturing systems considering dynamic production planning and worker assignments. Journal of Mathematics and System Science, 6, 1-15.

Altemeier, S., Helmdach, M., Koberstein, A., \& Dangelmaier, W. (2010). Reconfiguration of assembly lines under the influence of high product variety in the automotive industry-a decision support system. International Journal of Production Research, 48(21), 6235-6256.

Ammar, A., Pierreval, H., \& Elkosentini, S. (2013). Workers assignment problems in manufacturing systems: A literature analysis. In 5th International Conference on Industrial Engineering and Systems Management (IESM), Rabat, Morocco, 2013, pp. 1-7.

Andersen, A. L., Larsen, J. K., Brunoe, T. D., Nielsen, K., \& Ketelsen, C. (2018). Critical enablers of changeable and reconfigurable manufacturing and their industrial implementation. Journal of Manufacturing Technology Management, 29(6), 983-1002.

Anzanello, M. J., \& Fogliatto, F. S. (2007). Learning curve modelling of work assignment in mass customized assembly lines. International Journal of Production Research, 45(13), 29192938.

Aroui, K., Alpan, G., \& Frein, Y. (2017). Minimising work overload in mixed-model assembly 
lines with different types of operators: a case study from the truck industry. International Journal of Production Research, 55(21), 6305-6326.

Aryanezhad, M. B., Deljoo, V., \& Mirzapour Al-e-Hashem, S. M. J. (2009). Dynamic cell formation and the worker assignment problem: a new model. The International Journal of Advanced Manufacturing Technology, 41(3-4), 329.

Asensio-Cuesta, S., Diego-Mas, J. A., Canós-Darós, L., \& Andrés-Romano, C. (2012). A genetic algorithm for the design of job rotation schedules considering ergonomic and competence criteria. The International Journal of Advanced Manufacturing Technology, 60(9-12), 11611174.

Askin, R. G. (2013). Contributions to the design and analysis of cellular manufacturing systems. International Journal of Production Research, 51(23-24), 6778-6787.

Askin, R., \& Huang, Y. (1997). Employee training and assignment for facility reconfiguration. In G. L. Curry (Ed.), Industrial Engineering Research - Conference Proceedings (pp. 426-431). IIE.

Baker, K. R. (1976). Workforce allocation in cyclical scheduling problems: A survey. Journal of the Operational Research Society, 27(1), 155-167.

Bartholdi III, J. J., Bunimovich, L. A., \& Eisenstein, D. D. (1999). Dynamics of two-and threeworker "bucket brigade" production lines. Operations Research, 47(3), 488-491.

Bartholdi, J. J., \& Eisenstein, D. D. (1996). A production line that balances itself. Operations Research, 44(1), 21-34.

Bartholdi, J. J., Eisenstein, D. D., \& Foley, R. D. (2001). Performance of bucket brigades when work is stochastic. Operations Research, 49(5), 710-719.

Bartholdi, J. J., Eisenstein, D. D., \& Lim, Y. F. (2009). Deterministic chaos in a model of discrete manufacturing. Naval Research Logistics, 56(4), 293-299.

Battaïa, O., \& Dolgui, A. (2013). A taxonomy of line balancing problems and their solution approaches. International Journal of Production Economics, 142(2), 259-277.

Battaïa, O., Delorme, X., Dolgui, A., Hagemann, J., Horlemann, A., Kovalev, S., \& Malyutin, S. (2015). Workforce minimization for a mixed-model assembly line in the automotive industry. International Journal of Production Economics, 170, 489-500.

Battini, D., Faccio, M., Ferrari, E., Persona, A., \& Sgarbossa, F. (2007). Design configuration for a mixed-model assembly system in case of low product demand. The International Journal of Advanced Manufacturing Technology, 34(1-2), 188-200.

Baykasoğlu, A., Topaloğlu, Ş., \& Şenyüzlüler, F. (2018). Manufacturing cell formation with flexible processing capabilities and worker assignment: Comparison of constraint programming and integer programming approaches. Proceedings of the Institution of Mechanical Engineers, Part B: Journal of Engineering Manufacture, 232(11), 2054-2068.

Bellgran, M., \& Säfsten, E. K. (2009). Production development: design and operation of production systems. London, UK: Springer Science \& Business Media.

Benjaafar, S., Heragu, S. S., \& Irani, S. A. (2002). Next generation factory layouts: research challenges and recent progress. Interfaces, 32(6), 58-76.

Bidanda, B., Ariyawongrat, P., Needy, K. L., Norman, B. A., \& Tharmmaphornphilas, W. (2005). Human related issues in manufacturing cell design, implementation, and operation: a review and survey. Computers \& Industrial Engineering, 48(3), 507-523.

Biele, A., \& Mönch, L. (2018). Hybrid approaches to optimize mixed-model assembly lines in low-volume manufacturing. Journal of Heuristics, 24(1), 49-81.

Bischak, D. P. (1996). Performance of a manufacturing module with moving workers. IIE 
Transactions, 28(9), 723-733.

Bock, S., Rosenberg, O., \& van Brackel, T. (2006). Controlling mixed-model assembly lines in real-time by using distributed systems. European Journal of Operational Research, 168(3), 880-904.

Bokhorst, J. A., \& Gaalman, G. J. (2009). Cross-training workers in dual resource constrained systems with heterogeneous processing times. International Journal of Production Research, 47(22), 6333-6356.

Bokhorst, J. A. C., Slomp, J., \& Gaalman, G. J. C. (2004). On the who-rule in dual resource constrained (DRC) manufacturing systems. International Journal of Production Research, 42(23), 5049-5074.

Bortolini, M., Ferrari, E., Gabriele Galizia, F., Mora, C., \& Pilati, F. (2019). Optimal redesign of Cellular Flexible and Reconfigurable Manufacturing Systems. Procedia CIRP 81, 14351440.

Bortolini, M., Galizia, F. G., \& Mora, C. (2018). Reconfigurable manufacturing systems: Literature review and research trend. Journal of Manufacturing Systems, 49, 93-106.

Bouajaja, S., \& Dridi, N. (2017). A survey on human resource allocation problem and its applications. Operational Research, 17(2), 339-369.

Boysen, N., Fliedner, M., \& Scholl, A. (2008). Assembly line balancing: Which model to use when?. International Journal of Production Economics, 111(2), 509-528.

Boysen, N., Kiel, M., \& Scholl, A. (2011). Sequencing mixed-model assembly lines to minimise the number of work overload situations. International Journal of Production Research, 49(16), 4735-4760.

Bratcu, A. I., \& Dolgui, A. (2005). A survey of the self-balancing production lines ("bucket brigades"). Journal of Intelligent Manufacturing, 16(2), 139-158.

Bratcu, A. I., \& Dolgui, A. (2009). Some new results on the analysis and simulation of bucket brigades (self-balancing production lines). International Journal of Production Research, 47(2), 369-387.

Buyukkaramikli, N. C., Bertrand, J. W. M., and van Ooijen, H. P. (2013). Flexible hiring in a make to order system with parallel processing units. Annals of Operations Research, 209(1), 159178.

Campbell, G. M. (2011). A two-stage stochastic program for scheduling and allocating crosstrained workers. Journal of the Operational Research Society, 62(6), 1038-1047.

Campbell, G. M., \& Diaby, M. (2002). Development and evaluation of an assignment heuristic for allocating cross-trained workers. European Journal of Operational Research, 138(1), 9-20.

Celano, G., Costa, A., Fichera, S., \& Perrone, G. (2004). Human factor policy testing in the sequencing of manual mixed model assembly lines. Computers and Operations Research, 31(1), 39-59.

Cevikcan, E. (2016). An optimization methodology for multi model walking-worker assembly systems: an application from busbar energy distribution systems. Assembly Automation, 36(4), 439-459.

Cevikcan, E., \& Durmusoglu, M. B. (2011). Minimising utility work and utility worker transfers for a mixed-model assembly line. International Journal of Production Research, 49(24), $7293-7314$.

Chaves, A. A., Miralles, C., \& Lorena, L. A. N. (2007). Clustering search approach for the assembly line worker assignment and balancing problem. In Proceedings of the 37th International Conference on Computers and Industrial Engineering, Alexandria, Egypt (pp. 
1469-1478).

Chen, Q., Liao, S., Wu, Z., \& Yi, S. (2016). Comparative analysis of the performance of a novel U-shaped 'chasing-overtaking' production line. International Journal of Production Research, 54(12), 3677-3690.

Chu, X., Gao, D., Cheng, S., Wu, L., Chen, J., Shi, Y., \& Qin, Q. (2019). Worker assignment with learning-forgetting effect in cellular manufacturing system using adaptive memetic differential search algorithm. Computers \& Industrial Engineering, 136, 381-396.

Corominas, A., Pastor, R., \& Plans, J. (2008). Balancing assembly line with skilled and unskilled workers. Omega, 36(6), 1126-1132.

Cortez, P. M., \& Costa, A. M. (2015). Sequencing mixed-model assembly lines operating with a heterogeneous workforce. International Journal of Production Research, 53(11), 3419-3432.

Cronin, C., Conway, A., \& Walsh, J. (2019). Flexible manufacturing systems using IIoT in the automotive sector. Procedia Manufacturing 38, 1652-1659.

Davis, D. J., Kher, H. V., \& Wagner, B. J. (2009). Influence of workload imbalances on the need for worker flexibility. Computers \& Industrial Engineering, 57(1), 319-329.

De Bruecker, P., Van den Bergh, J., Beliën, J., \& Demeulemeester, E. (2015). Workforce planning incorporating skills: State of the art. European Journal of Operational Research, 243(1), 116.

Deepak, A., Srivatsan, R., \& Samsingh, V. (2017). A case study on implementation of walking worker assembly line to improve productivity and utilisation of resources in a heavy duty manufacturing industry. FME Transactions, 45(4), 496-502.

Delorme, X., Dolgui, A., Kovalev, S., \& Kovalyov, M. Y. (2019). Minimizing the number of workers in a paced mixed-model assembly line. European Journal of Operational Research, 272(1), 188-194.

Dolgui, A., \& Ihnatsenka, I. (2009). Branch and bound algorithm for a transfer line design problem: Stations with sequentially activated multi-spindle heads. European Journal of Operational Research, 197(3), 1119-1132.

Dolgui, A., Guschinsky, N., Levin G. (2009). Graph approach for optimal design of transfer machine with rotary table, International Journal of Production Research, 47(2), 321-341.

Dolgui, A., \& Proth, J. M. (2010). Supply chain engineering: useful methods and techniques. Springer Science \& Business Media.

Dolgui, A., Petroodi, S. E. H., Kovalev, S., Kovalyov, M. Y., \& Thevenin, S. (2019). Workforce planning and assignment in mixed-model assembly lines as a factor of line reconfigurability: state of the art. IFAC-PapersOnLine, 52(13), 2746-2751.

Dolgui, A., Kovalev, S., Kovalyov, M. Y., Malyutin, S., \& Soukhal, A. (2018). Optimal workforce assignment to operations of a paced assembly line. European Journal of Operational Research, 264(1), 200-211.

Easton, F. F. (2011). Cross-training performance in flexible labor scheduling environments. IIE Transactions, 43(8), 589-603.

Easton, F. F. (2014). Service completion estimates for cross-trained workforce schedules under uncertain attendance and demand. Production and Operations Management, 23(4), 660-675.

Ebeling, A. C., \& Lee, C. Y. (1994). Cross-training effectiveness and profitability. International Journal of Production Research, 32(12), 2843-2859.

Eğilmez, G., Erenay, B., \& Süer, G. A. (2014). Stochastic skill-based manpower allocation in a cellular manufacturing system. Journal of Manufacturing Systems, 33(4), 578-588.

ElMaraghy, H., Patel, V., \& Abdallah, I. Ben. (2000). Scheduling of manufacturing systems under 
dual-resource constraints using genetic algorithms. Journal of Manufacturing Systems, 19(3), 186-201.

ElMaraghy, H. A. (2005). Flexible and reconfigurable manufacturing systems paradigms. International Journal of Flexible Manufacturing Systems, 17(4), 261-276.

El Zaatari, S., Marei, M., Li, W., \& Usman, Z. (2019). Cobot programming for collaborative industrial tasks: an overview. Robotics and Autonomous Systems, 116, 162-180.

Ertay, T., \& Ruan, D. (2005). Data envelopment analysis based decision model for optimal operator allocation in CMS. European Journal of Operational Research, 164(3), 800-810.

Faccio, M., Gamberi, M., \& Bortolini, M. (2016). Hierarchical approach for paced mixed-model assembly line balancing and sequencing with jolly operators. International Journal of Production Research, 54(3), 761-777.

Feng, H., Da, W., Xi, L., Pan, E., \& Xia, T. (2017). Solving the integrated cell formation and worker assignment problem using particle swarm optimization and linear programming. Computers and Industrial Engineering, 110, 126-137.

Fowler, J. W., Wirojanagud, P., \& Gel, E. S. (2008). Heuristics for workforce planning with worker differences. European Journal of Operational Research, 190(3), 724-740.

Francas, D., Löhndorf, N., \& Minner, S. (2011). Machine and labor flexibility in manufacturing networks. International Journal of Production Economics, 131(1), 165-174.

Gebennini, E., Zeppetella, L., Grassi, A., \& Rimini, B. (2018). Optimal job assignment considering operators' walking costs and ergonomic aspects. International Journal of Production Research, 56(3), 1249-1268.

Gyulai, D., Kádár, B., \& Monostori, L. (2017). Scheduling and operator control in reconfigurable assembly systems. Procedia CIRP, 63, 459-464.

Harari, N. S., Fundin, A., \& Carlsson, A. L. (2018). Components of the design process of flexible and reconfigurable assembly systems. Procedia Manufacturing, 25, 549-556.

Hashemi-Petroodi, S. E., Thevenin, S., Kovalev, S., \& Dolgui, A. (2020). Operations management issues in design and control of hybrid human-robot collaborative manufacturing systems: a survey. Annual Reviews in Control, 49, 264-276.

Hopp, W. J., Tekin, E., \& Van Oyen, M. P. (2004). Benefits of skill chaining in serial production lines with cross-trained workers. Management Science, 50(1), 83-98.

Hottenstein, M. P., \& Bowman, S. A. (1998). Cross-training and worker flexibility: A review of DRC system research. Journal of High Technology Management Research, 9(2), 157-174.

Hytonen, J., Niemi, E., \& Toivonen, V. (2008). Optimal workforce allocation for assembly lines for highly customised low-volume products. International Journal of Services Operations and Informatics, 3(1), 28-39.

Hyun, C. J., Kim, Y. K., \& Kim, Y. K. (1998). A genetic algorithm for multiple objective sequencing problems in mixed model assembly lines. Computers \& Operations Research, 25(7-8), 675-690.

Inman, R. R., Jordan, W. C., \& Blumenfeld, D. E. (2004). Chained cross-training of assembly line workers. International Journal of Production Research, 42(10), 1899-1910.

Jaehn, F., \& Sedding, H. A. (2016). Scheduling with time-dependent discrepancy times. Journal of Scheduling, 19(6), 737-757.

Kaku, I., Murase, Y., \& Yin, Y. (2008). A study on human-task-related performances in converting conveyor assembly line to cellular manufacturing. European Journal of Industrial Engineering, 2(1), 17-34.

Kellegöz, T. (2017). Assembly line balancing problems with multi-manned stations: a new 
mathematical formulation and Gantt based heuristic method. Annals of Operations Research, 253(1), 377-404.

Kim, D., Moon, D.H. and Moon, I. (2018), Balancing a mixed-model assembly line with unskilled temporary workers: algorithm and case study, Assembly Automation, 38(4), 511-523.

Kim, S., \& Nembhard, D. A. (2013). Rule mining for scheduling cross training with a heterogeneous workforce. International Journal of Production Research, 51(8), 2281-2300.

Koo, P.-H. (2009). The use of bucket brigades in zone order picking systems. OR Spectrum, 31(4), 759.

Koren, Y., Heisel, U., Jovane, F., Moriwaki, T., Pritschow, G., Ulsoy, G., \& Van Brussel, H. (1999). Reconfigurable manufacturing systems. CIRP Annals, 48(2), 527-540.

Kucukkoc, I., \& Zhang, D. Z. (2014). Simultaneous balancing and sequencing of mixed-model parallel two-sided assembly lines. International Journal of Production Research, 52(12), 3665-3687.

Kucukkoc, I., \& Zhang, D. Z. (2016). Mixed-model parallel two-sided assembly line balancing problem: A flexible agent-based ant colony optimization approach. Computers and Industrial Engineering, 97, 58-72.

Kuo, Y., \& Liu, C. C. (2017). Operator assignment in a labor-intensive manufacturing cell considering inter-cell manpower transfer. Computers and Industrial Engineering, 110, 8391.

Lee, D.-K., Shin, J.-H., \& Lee, D.-H. (2020). Operations scheduling for an advanced flexible manufacturing system with multi-fixturing pallets. Computers \& Industrial Engineering, 144, 106496.

Li, J., \& Gao, J. (2014). Balancing manual MMALs using overtime work in a demand variation environment. International Journal of Production Research, 52(12), 3552-3567.

Lian, J., Liu, C. G., Li, W. J., \& Yin, Y. (2018). A multi-skilled worker assignment problem in seru production systems considering the worker heterogeneity. Computers and Industrial Engineering, 118, 366-382.

Lim, Y. F. (2011). Cellular bucket brigades. Operations Research, 59(6), 1539-1545.

Lim, Y. F. (2012). Order-picking by cellular bucket brigades: a case study. In: Manzini R. (eds) Warehousing in the Global Supply Chain. Springer, London, (pp. 71-85).

Lim, Y. F. (2017). Performance of cellular bucket brigades with hand-off times. Production and Operations Management, 26(10), 1915-1923.

Lim, Y. F., \& Wu, Y. (2014). Cellular bucket brigades on U-lines with discrete work stations. Production and Operations Management, 23(7), 1113-1128.

Lim, Y. F., \& Yang, K. K. (2009). Maximizing throughput of bucket brigades on discrete work stations. Production and Operations Management, 18(1), 48-59.

Liu, C., Wang, J., Leung, J. Y.-T., \& Li, K. (2016). Solving cell formation and task scheduling in cellular manufacturing system by discrete bacteria foraging algorithm. International Journal of Production Research, 54(3), 923-944.

Mahdavi, I., Aalaei, A., Paydar, M. M., \& Solimanpur, M. (2010). Designing a mathematical model for dynamic cellular manufacturing systems considering production planning and worker assignment. Computers and Mathematics with Applications, 60(4), 1014-1025.

Makssoud, F., Battaïa, O., \& Dolgui, A. (2020). Multi-objective Approach and Model for Transfer Line Reconfigurations. In Reconfigurable Manufacturing Systems: From Design to Implementation (pp. 193-208). Springer International Publishing, Cham.

Makssoud, F., Battaïa, O., Dolgui, A. (2014). An exact optimization approach for a Transfer Line 
Reconfiguration Problem, International Journal of Advanced Manufacturing Technology, 72, 717-727.

Manavizadeh, N., Hosseini, N. S., Rabbani, M., \& Jolai, F. (2013). A simulated annealing algorithm for a mixed model assembly U-line balancing type-I problem considering human efficiency and just-in-time approach. Computers and Industrial Engineering, 64(2), 669-685.

McCreery, J. K., \& Krajewski, L. J. (1999). Improving performance using workforce flexibility in an assembly environment with learning and forgetting effects. International Journal of Production Research, 37(9), 2031-2058.

Mehrabi, M. G., Ulsoy, A. G., \& Koren, Y. (2000). Reconfigurable manufacturing systems: Key to future manufacturing. Journal of Intelligent Manufacturing, 11(4), 403-419.

Mehrabi, M. G., Ulsoy, A. G., Koren, Y., \& Heytler, P. (2002). Trends and perspectives in flexible and reconfigurable manufacturing systems. Journal of Intelligent Manufacturing, 13(2), 135146.

Méndez-Vázquez, Y. M., \& Nembhard, D. A. (2019). Worker-cell assignment: The impact of organizational factors on performance in cellular manufacturing systems. Computers \& Industrial Engineering, 127, 1101-1114.

Miralles, C., García-Sabater, J. P., Andrés, C., \& Cardós, M. (2008). Branch and bound procedures for solving the assembly line worker assignment and balancing problem: Application to sheltered work centres for disabled. Discrete Applied Mathematics, 156(3), 352-367.

Moreira, M. C. D. O., \& Costa, A. M. (2009). A minimalist yet efficient tabu search algorithm for balancing assembly lines with disabled workers. Anais do XLI Simpósio Brasileiro de Pesquisa Operacional. Porto Seguro, Brazil, 660-671.

Mura, M. D., \& Dini, G. (2016). Worker Skills and Equipment Optimization in Assembly Line Balancing by a Genetic Approach. Procedia CIRP, 44, 102-107.

Naderi, B., Azab, A., \& Borooshan, K. (2019). A realistic multi-manned five-sided mixed-model assembly line balancing and scheduling problem with moving workers and limited workspace. International Journal of Production Research, 57(3), 643-661.

Nakade, K., \& Nishiwaki, R. (2008). Optimal allocation of heterogeneous workers in a U-shaped production line. Computers \& Industrial Engineering, 54(3), 432-440.

Nakade, K., \& Ohno, K. (1995). Reversibility and dependence in a U-shaped production line. Queueing Systems, 21(1-2), 183-197.

Nakade, K., \& Ohno, K. (1999). An optimal worker allocation problem for a U-shaped production line. International Journal of Production Economics, 60, 353-358.

Nikoofarid, E., \& Aalaei, A. (2012). Production planning and worker assignment in a dynamic virtual cellular manufacturing system. International Journal of Management Science and Engineering Management, 7(2), 89-95.

Norman, B. A., Tharmmaphornphilas, W., Needy, K. L., Bidanda, B., \& Warner, R. C. (2002). Worker assignment in cellular manufacturing considering technical and human skills. International Journal of Production Research, 40(6), 1479-1492.

Otto, A., \& Battaïa, O. (2017). Reducing physical ergonomic risks at assembly lines by line balancing and job rotation: A survey. Computers \& Industrial Engineering, 111, 467-480.

Özcan, U. (2018). Balancing stochastic parallel assembly lines. Computers and Operations Research, 99, 109-122.

Papaioannou, G., \& Wilson, J.M. (2010). The evolution of cell formation problem methodologies based on recent studies (1997-2008): Review and directions for future research. European Journal of Operational Research, 206(3), 509-521. 
Peruzzini, M., \& Pellicciari, M. (2017). A framework to design a human-centred adaptive manufacturing system for aging workers. Advanced Engineering Informatics, 33, 330-349.

Pröpster, M., März, L., Reinhart, G., \& Intra, C. (2015). Validation of line balancing by simulation of workforce flexibility. Procedia CIRP, 33, 93-98.

Qin, R., Nembhard, D. A., \& Barnes II, W. L. (2015). Workforce flexibility in operations management. Surveys in Operations Research and Management Science, 20(1), 19-33.

Quader, S. (2013). A state-of-the-art matrix analysis of bucket brigade. In IIE Annual Conference. Proceedings (p. 1255-1264). Institute of Industrial and Systems Engineers, San juan, Puerto Rico.

Quintana, R., Leung, M. T., Rene Villalobos, J., \& Graul, M. (2009). Corrective maintenance through dynamic work allocation and pre-emption: case study and application. International Journal of Production Research, 47(13), 3539-3557.

Rajamani, D., Singh, N., and Aneja, (1990). Integrated design of cellular manufacturing systems in the presence of alternate process plans. International Journal of Production Research, 28 (8), 1541-1554.

Rekiek, B., Dolgui, A., Delchambre, A., \& Bratcu, A. (2002). State of art of optimization methods for assembly design. Annual Reviews in Control, 26(2), 163-174.

Safaei, N., Saidi-Mehrabad, M., \& Jabal-Ameli, M.S. (2008). A hybrid simulated annealing for solving an extended model of dynamic cellular manufacturing system. European Journal of Operational Research, 185, 563-592.

Satoglu, S. I., \& Suresh, N. C. (2009). A goal-programming approach for design of hybrid cellular manufacturing systems in dual resource constrained environments. Computers \& Industrial Engineering, 56(2), 560-575.

Savino, M. M., Brun, A., \& Mazza, A. (2014). Dynamic workforce allocation in a constrained flow shop with multi-agent system. Computers in Industry, 65(6), 967-975.

Sayin, S., \& Karabati, S. (2007). Assigning cross-trained workers to departments: A two-stage optimization model to maximize utility and skill improvement. European Journal of Operational Research, 176(3), 1643-1658.

Schrader, G.F., Elshennawy, A.K. (2000). Manufacturing processes and materials. Society of manufacturing Engineers, Dearborn, Michigan, USA.

Sennott, L. I., Van Oyen, M. P., \& Iravani, S. M. (2006). Optimal dynamic assignment of a flexible worker on an open production line with specialists. European Journal of Operational Research, 170(2), 541-566.

Shewchuk, J. P. (2008). Worker allocation in lean U-shaped production lines. International Journal of Production Research, 46(13), 3485-3502.

Shttjb, A. (1984). The effect of incompletion cost on line balancing with multiple manning of work stations. International Journal of Production Research, 22(2), 235-245.

Sikora, C. G. S., Lopes, T. C., \& Magatão, L. (2017). Traveling worker assembly line (re) balancing problem: Model, reduction techniques, and real case studies. European Journal of Operational Research, 259(3), 949-971.

Simaria, A. S., Zanella De Sá, M., \& Vilarinho, P. M. (2009). Meeting demand variation using flexible U-shaped assembly lines. International Journal of Production Research, 47(14), 3937-3955.

Singh, N. (1993). Design of cellular manufacturing systems: an invited review. European Journal of Operational Research, 69(3), 284-291.

Sirovetnukul, R., \& Chutima, P. (2010). The impact of walking time on U-shaped assembly line 
worker allocation problems. Engineering Journal, 14(2), 53-78.

Slomp, J., Bokhorst, J. A., \& Molleman, E. (2005). Cross-training in a cellular manufacturing environment. Computers \& Industrial Engineering, 48(3), 609-624.

Song, J., Zhang, B. X., \& Guan, Y. Y. (2011). Study on Balance Points of Bucket Brigade Lines with Return Velocities. Advanced Materials Research, 314, 2273-2277. https://doi.org/10.4028/www.scientific.net/amr.314-316.2273

Soolaki, M. (2012). A multi-objective integrated cellular manufacturing systems design with production planning, worker assignment and dynamic system reconfiguration. International Journal of Industrial and Systems Engineering, 12(3), 280-300.

Sparling, D., \& Miltenburg, J. (1998). The mixed-model U-line balancing problem. International Journal of Production Research, 36(2), 485-501.

Sriram, S., Kuhl, M. E., Thorn, B. K., \& Carrano, A. L. (2014). A novel work-sharing protocol for U-shaped assembly lines. Proceedings of the Winter Simulation Conference 2014, Savanah, GA, 2014, pp. 2113-2123, doi: 10.1109/WSC.2014.7020056.

Stratman, J. K., Roth, A. V., \& Gilland, W. G. (2004). The deployment of temporary production workers in assembly operations: a case study of the hidden costs of learning and forgetting. Journal of Operations Management, 21(6), 689-707.

Stadnicka, D., Antonelli, D., \& Bruno, G. (2017). Work sequence analysis and computer simulations of value flow and workers' relocations: a case study. Procedia CIRP, 62, 159164.

Stecke, K. E., \& Aronson, J. E. (1985). Review of operator/machine interference models. International Journal of Production Research, 23(1), 129-151.

Süer, G. A., \& Dagli, C. (2005). Intra-cell manpower transfers and cell loading in labor-intensive manufacturing cells. Computers \& Industrial Engineering, 48(3), 643-655.

Sungur, B., \& Yavuz, Y. (2015). Assembly line balancing with hierarchical worker assignment. Journal of Manufacturing Systems, 37, 290-298.

Tapkan, P., Özbakır, L., \& Baykasoğlu, A. (2016). Bee algorithms for parallel two-sided assembly line balancing problem with walking times. Applied Soft Computing, 39, 275-291.

Techawiboonwong, A., Yenradee, P., \& Das, S. K. (2006). A master scheduling model with skilled and unskilled temporary workers. International Journal of Production Economics, 103(2), 798-809.

Tekin, E., Hopp, W. J., \& Van Oyen, M. P. (2002). Benefits of skill chaining in production lines with cross-trained workers. Manufacturing \& Service Operations Management, 4(1), 17-20.

Thongsanit, K., Boondisakulchok, R., \& Tharmmaphornphilas, W. (2010). Heuristic for taskworker assignment with varying learning slopes. Engineering Journal, 14(2), 1-14.

Treleven, M. (1989). A review of the dual resource constrained system research. IIE Transactions, 21(3), 279-287.

Lai, T. C., Sotskov, Y. N., \& Dolgui, A. (2019). The stability radius of an optimal line balance with maximum efficiency for a simple assembly line. European Journal of Operational Research, 274(2), 466-481.

Vairaktarakis, G., Szmerekovsky, J. G., \& Xu, J. (2016). Level workforce planning for multistage transfer lines. Naval Research Logistics, 63(7), 577-590.

Vairaktarakis, G., \& Winch, J. K. (1999). Worker cross-training in paced assembly lines. Manufacturing \& Service Operations Management, 1(2), 112-131.

Van Den Bergh, J., Beliën, J., De Bruecker, P., Demeulemeester, E., \& De Boeck, L. (2013). Personnel scheduling: A literature review. European Journal of Operational Research, 
226(3), 367-385.

Villalobos, J. R., Gutiérrez, M. A., Mar, L. R., Sánchez, O., \& Ahumada, O. (2011). The use of dynamic work sharing production methods to reduce the impact of labour turnover in serial assembly lines. International Journal of Manufacturing Technology and Management, 23(12), 34-53.

Wang, Q., Lassalle, S., Mileham, A. R., \& Owen, G. W. (2009). Analysis of a linear walking worker line using a combination of computer simulation and mathematical modeling approaches. Journal of Manufacturing Systems, 28(2-3), 64-70.

Wang, Q., Lassalle, S., Mileham, A. R., \& Owen, G. W. (2010). Analysis of production loss on a linear walking worker line. International Journal of Industrial and Manufacturing Engineering, 4(5), 454-458.

Wang, Q., Owen, G. W., \& Mileham, A. R. (2007). Determining numbers of workstations and operators for a linear walking-worker assembly line. International Journal of Computer Integrated Manufacturing, 20(1), 1-10.

Wang, Q., Sowden, M., \& Mileham, A. R. (2013). Modelling human performance within an automotive engine assembly line. The International Journal of Advanced Manufacturing Technology, 68(1-4), 141-148.

Webster, S., Ruben, R. A., \& Yang, K. (2012). Impact of storage assignment decisions on a bucket brigade order picking line. Production and Operations Management, 21(2), 276-290.

Widyadana, G. A. (2009). Multi objective model for balancing U-type assembly line with permanent and temporary workers. Jurnal Teknik Industri, 11(1), 33-42.

Winch, J. K., Cai, X., \& Vairaktarakis, G. L. (2007). Cyclic job scheduling in paced assembly lines with cross-trained workers. International Journal of Production Research, 45(4), 803-828.

Wu, L., Cai, F., Li, L., \& Chu, X. (2018). Cross-trained worker assignment problem in cellular manufacturing system using swarm intelligence metaheuristics. Mathematical Problems in Engineering, 2018, 1-15.

$\mathrm{Xu}, \mathrm{J} ., \mathrm{Xu}, \mathrm{X} .$, \& Xie, S. Q. (2011). Recent developments in dual resource constrained (DRC) system research. European Journal of Operational Research, 215(2), 309-318.

Xu, Z., Ming, X. G., Zheng, M., Li, M., He, L., \& Song, W. (2015). Cross-trained workers scheduling for field service using improved NSGA-II. International Journal of Production Research, 53(4), 1255-1272.

Yaakob, S. B., \& Watada, J. (2009). Particle swarm optimization for multi-function worker assignment problem. In: Velásquez J.D., Ríos S.A., Howlett R.J., Jain L.C. (eds) KnowledgeBased and Intelligent Information and Engineering Systems. KES 2009. Lecture Notes in Computer Science, vol 5712, (pp. 203-211). Springer, Berlin, Heidelberg.

Yang, C., \& Gao, J. (2016). Balancing mixed-model assembly lines using adjacent cross-training in a demand variation environment. Computers \& Operations Research, 65, 139-148.

Yang, C., Gao, J., \& Sun, L. (2013). A multi-objective genetic algorithm for mixed-model assembly line rebalancing. Computers and Industrial Engineering, 65(1), 109-116.

Yoo, J. K., Shimizu, Y., \& Hino, R. (2005). A sequencing problem for mixed-model assembly line with the aid of relief-man. International Journal Series C-Mechanical Systems Machine Elements and Manufacturing, 48(1), 15-20.

Yue, H., Slomp, J., Molleman, E., \& Van Der Zee, D. J. (2008). Worker flexibility in a parallel dual resource constrained job shop. International Journal of Production Research, 46(2), 451-467.

Zavadlav, E., McClain, J. O., \& Thomas, L. J. (1996). Self-buffering, self-balancing, self-flushing 
production lines. Management Science, 42(8), 1151-1164.

Zhao, X., Ohno, K., \& Lau, H. S. (2004). A balancing problem for mixed model assembly lines with a paced moving conveyor. Naval Research Logistics, 51(3), 446-464.

Zhou, J., Wang, X., \& Zhang, Q. (2017). Characteristics analysis of cellular bucket brigades with different constraints. The International Journal of Advanced Manufacturing Technology, 93(1-4), 153-159. 